\title{
Flow separation at the inner (convex) and outer (concave) banks of constant-width and widening open-channel bends
}

\author{
Koen Blanckaert, ${ }^{1,6 *}$ Maarten G. Kleinhans, ${ }^{2}$ Stuart J. McLelland, ${ }^{3}$ Wim S. J. Uijttewaal, ${ }^{4}$ Brendan J. Murphy, ${ }^{3}$ Anja van deKruijs, ${ }^{2}$ \\ Daniel R. Parsons ${ }^{5}$ and Qiuwen Chen ${ }^{1}$ \\ ${ }^{1}$ State Key Laboratory of Urban and Regional Ecology, Research Centre for Eco-Environmental Sciences, Chinese Academy of \\ Sciences, Beijing, China \\ ${ }^{2}$ Faculty of Geosciences, Universiteit Utrecht, Utrecht, The Netherlands \\ ${ }^{3}$ Department of Geography, Environment and Earth Sciences, University of Hull, Hull, UK \\ ${ }^{4}$ Faculty of Civil Engineering and Geosciences, Delft University of Technology, Delft, The Netherlands \\ ${ }^{5}$ University of Hull, Hull, UK \\ ${ }^{6}$ École Polytechnique Fédérale de Lausanne, Lausanne, Switzerland
}

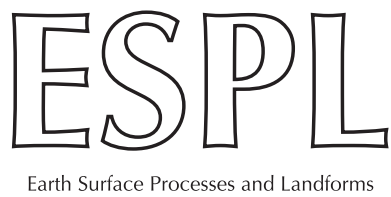

ABSTRACT: There is a paucity of data and insight in the mechanisms of, and controls on flow separation and recirculation at natural sharply-curved river bends. Herein we report on successful laboratory experiments that elucidate flow structure in one constant-width bend and a second bend with an outer-bank widening. The experiments were performed with both a flat immobile gravel bed and mobile sand bed with dominant bedload sediment transport.

In the constant-width bend with immobile bed, a zone of mainly horizontal flow separation (vertical rotational axis) formed at the inner bank that did not contain detectable flow recirculation, and an outer-bank cell of secondary flow with streamwise oriented rotational axis. Surprisingly, the bend with widening at the outer bank and immobile bed did not lead to a transverse expansion of the flow. Rather, flow in the outer-bank widening weakly recirculated around a vertical axis and hardly interacted with the inner part of the bend, which behaved as a constant-width bend.

In the mobile bed experiment, downstream of the bend apex a pronounced depositional bar developed at the inside of the bend and pronounced scour occurred at the outside. Moreover the deformed bed promoted flow separation over the bar, including return currents. In the constant-width bend, the topographic steering impeded the generation of an outer-bank cell of secondary flow. In the bend with outer-bank widening, the topographic steering induced an outward expansion of the flow, whereby the major part of the discharge was conveyed in the central part of the widening section. Flow in the outer-bank widening was highly three dimensional and included return currents near the bottom.

In conclusion, the experiments elucidated three distinct processes of flow separation common in sharp bends: flow separation at the inner bank, an outer-bank cell of secondary flow, and flow separation and recirculation in an outer-bank widening. Copyright (C) 2012 John Wiley \& Sons, Ltd.

KEYWORDS: flow separation; open-channel bend; experiments; morphology; laboratory

\section{Introduction}

\section{Problem definition and objective}

Changes in the direction of channel boundaries that lead to an adverse pressure gradient or induce sufficient inertia within the flow will produce flow separation from the boundary, which often leads to the formation of a zone of flow recirculation. This has frequently been observed in flows around engineering structures such as bridge piers. Such flow features also occur naturally and are observed over a range of scales around naturally created morphological elements such as individual clasts (e.g. Best and Brayshaw, 1985), bedforms (e.g. Bennett and Best, 2006), at confluence zones (e.g. Best and Reid, 1984), downstream of bars in bedrock controlled canyons (Schmidt, 1990; Schmidt et al., 1993; Wright and Kaplinski, 2011) and in river bends (e.g. Bagnold, 1960; Leeder and Bridges, 1975; Hickin, 1977, 1978, 1986; Hickin and Nanson, 1984; Jackson, 1992; Andrle, 1994; Hodskinson and Ferguson, 1998; Ferguson et al., 2003; Kleinhans et al., 2009; Rhoads and Massey, 2012; Parsons, 2003; Vietz et al., 2012; Schnauder and Sukhodolov, 2012).

Flow separation and the formation of recirculation zones have broad and significant consequences for the morphodynamics of a river. The presence of a separation zone combined with a recirculation vortex can decrease the effective channel width 
and thus reduce the channel conveyance capacity. This can alter patterns of bed and bank erosion and can often lead to localized and focused bank erosion (Ferguson et al., 2003; Kleinhans et al., 2009; Parsons, 2003) and formation of a muddy counter-point bar (e.g. Nanson and Page, 1983; Makaske and Weerts, 2005) with potential impacts on both ecological diversity and floodplain sedimentology (e.g. Burge and Smith, 1999): particularly as such zones are loci for fine-grained sedimentation, which would otherwise only be possible on floodplains. At river bifurcations, deposition and bar formation within a recirculation zone can eventually lead to closure of one bifurcate arm and complete channel avulsion (Bulle, 1926; Hirose et al., 2003; Kleinhans et al., 2012). Enhancing knowledge on flow separation near the banks is thus vital for informing environmental management strategies, enhancing modelling capabilities, improving design of civil engineering controls (bank protection and shipping depth) and for informing longer-term investigations in sedimentary geology. It is particularly relevant within the context of the recent trend to re-naturalize smaller sinuous channels, where sharp bends are expected because of the relatively strong banks. Such sinuous streams are often thought of as meandering with associated biota, but their dynamics in natural states were probably very low. Hence sharp bends could be integrated in the design to obtain favourable conditions, including more dynamics and spatial variation of microenvironments.

This paper will focus on flow separation and flow recirculation in open-channel bends. The hydrodynamic and morphodynamic processes in open-channel bends have been abundantly investigated in the past by means of field measurements (e.g. Rozovskii, 1957; Bathurst et al., 1979; de Vriend and Geldof, 1983; Dietrich and Smith, 1983; Dietrich, 1987; Ferguson et al., 2003; Frothingham and Rhoads, 2003; Nanson, 2010; Rhoads and Massey, 2012; Schnauder and Sukhodolov, 2012; Vietz et al., 2012), laboratory experiments (e.g. Rozovskii, 1957; Odgaard and Bergs, 1988; Blanckaert and Graf, 2001; Abad and Garcia, 2009; Blanckaert, 2010; Jamieson et al., 2010; Termini and Piraino, 2011) and numerical modelling (e.g. Kikkawa et al., 1976; Leschziner and Rodi, 1979; Shimizu and Itakura, 1989; Hodskinson and Ferguson, 1998; Wu et al., 2000; Ferguson et al., 2003; Khosronejad et al., 2007; Zeng et al., 2008; Stoesser et al., 2010; van Balen et al., 2010b; Constantinescu et al., 2011; Kang and Sotiropoulos, 2011). This previous work mainly focussed on the central region (i.e. away from the banks) of the cross-section, particularly the nature of the secondary flow field.

Secondary flow is defined in the present paper as the flow component perpendicular to the channel axis. The key feature of flow in curved open-channels is the helical motion in the central part of the cross-section, with inward velocities near the bed and outward velocities near the water surface. This helical motion is essentially due to the curvature-induced local imbalance between the outwards centrifugal force and the inwards pressure gradient caused by the transverse tilting of the water surface (e.g. Boussinesq, 1868; Thomson, 1876; van Bendegom, 1947; Rozovskii, 1957). This helical motion gives rise to a secondary flow cell in the central region of the cross-section, which will be called 'centre-region cell of secondary flow' henceforward. The centre-region cell of secondary flow causes near-bed velocities that are inwards directed and lead to the development of a transverse bed slope (van Bendegom, 1947; Rozovskii, 1957; Engelund, 1974; Odgaard, 1981). It also contributes to the redistribution of the flow in open-channel bends (Rozovskii, 1957; Engelund, 1974; de Vriend, 1977, 1981; Yeh and Kennedy, 1993; Blanckaert and de Vriend, 2003, 2010; Blanckaert and Graf, 2004).
The details of the hydrodynamic and morphodynamic processes occurring near the banks of open-channel bends have only rarely been investigated (Table I) in spite of their importance with respect to bank erosion, bank accretion, river planform dynamics and hazard mitigation. In the present paper, the term flow separation refers to distinct hydrodynamic processes that cause the main flow body to be separated from the channel banks. The objective of this paper is to understand formative conditions and flow structure of three distinct processes of flow separation at channel bends: flow separation at the inner bank, the outer-bank cell of secondary flow and flow separation at a widening outer bank. The three processes will be explored experimentally with and without a mobile bed to assess the relevance for full-scale, natural river channel processes and dynamics.

\section{Review}

Flow separation at the inner bank (horizontal around a vertical axis)

Flow separation and recirculation at the inner bank, has been observed in a number of studies of natural meander bends (e.g. Bagnold, 1960; Leeder and Bridges, 1975; Ferguson et al., 2003; Frothingham and Rhoads, 2003; Nanson, 2010; Rhoads and Massey, 2012; Schnauder and Sukhodolov, 2012). Ferguson et al. (2003) highlighted that flow separation from the channel bank occurred in about $50 \%$ of bends on a sinuous river with relatively cohesive banks, where the barpool morphology acts to divide the cross-section into two distinct regions: a shallow point bar at the inside of the bend and a deep scour pool at the outside of the bend. Bagnold (1960) argued that flow separation at the inner bank concentrates the flow into the deeper outer part of the crosssection. Leeder and Bridges (1975) also speculated that flow separation at the inner bank reduces the effective width and directs high-velocity flow towards the outer bank. Ferguson et al. (2003), however, found that the reduced effective width is more than offset by an increase in flow depth and that the flow decelerates along the outer bank at the flow stage they investigated. Detailed measurements in a laboratory flume by Blanckaert (2011) clarified these seemingly contradictory results. Blanckaert (2011) found that the reduced effective width is indeed more than offset by an increase of flow depth, and that the flow globally decelerates along the outer bank. But the cross-sectional flow patterns revealed that the velocity increases near the toe of the outer-bank, where the bank is most vulnerable to erosion. Flow separation at the inner bank that directs the flow towards the outer bank thus influences the patterns of bank erosion, bar formation and sedimentary deposits (Burge and Smith, 1999).

This 'sharp bend style' of river bend development is often associated with channels that have relatively strong banks and limited meandering dynamics (Ferguson, 1987; Kleinhans et al., 2009; see Kleinhans, 2010, for review), but have also been observed in channels that are more laterally active (Hickin and Nanson, 1975; Hodskinson and Ferguson, 1998 Ferguson et al., 2003). According to Leeder and Bridges (1975), inner-bank flow separation is largely controlled by the ratio of channel width to centreline radius of curvature, $B / R$ and the Froude number $\mathrm{Fr}$, whereby an increase in bend tightness and Froude number favours flow separation. Bagnold (1960), on the contrary, rejected the use of the Froude number citing that separation in pipes is similar to separation in openchannel flows, but Fr can only be defined for open-channel flow. The role of turbulence in the generation of inner-bank flow separation can also be important as highlighted by recent 
Table I. Available experimental data including the three components of the mean velocity and turbulence characteristics in the near-bank zones.

\begin{tabular}{|c|c|c|}
\hline Reference & Configuration & Measured physical quantities \\
\hline \multicolumn{3}{|c|}{ Inner bank flow separation and recirculation } \\
\hline Frothingham and Rhoads (2003) & $\begin{array}{l}\text { Sharply-curved bend on the Embarras } \\
\text { River }\end{array}$ & $\begin{array}{l}\text { Measurements including the three mean velocity } \\
\text { components on a relatively coarse grid }\end{array}$ \\
\hline Ferguson et al. (2003) & $\begin{array}{l}\text { Two sharply-curved bends on the River } \\
\text { Dean }\end{array}$ & $\begin{array}{l}\text { Measurements including the three mean velocity } \\
\text { components at a few points }\end{array}$ \\
\hline Nanson (2010) & $\begin{array}{l}\text { Sharply curved natural bend with outer-bank } \\
\text { widening }\end{array}$ & $\begin{array}{l}\text { Measurements including the three mean velocity } \\
\text { components at a few points }\end{array}$ \\
\hline Blanckaert $(2010,2011)$ & $\begin{array}{l}\text { Sharply-curved laboratory flume with mobile } \\
\text { bed and smooth vertical banks. }\end{array}$ & $\begin{array}{l}\text { Measurements with high temporal and spatial } \\
\text { resolution, including the three mean velocity }\end{array}$ \\
\hline Blanckaert (2011) & $\begin{array}{l}\text { Sharply-curved laboratory flume with flat } \\
\text { immobile bed and smooth vertical banks. }\end{array}$ & $\begin{array}{l}\text { components, the six turbulent stresses, higher-order } \\
\text { turbulent correlations and the turbulent dissipation } \\
\text { rate. }\end{array}$ \\
\hline Schnauder and Sukhodolov (2012) & $\begin{array}{l}\text { Sharply-curved natural bend with outer-bank } \\
\text { widening }\end{array}$ & $\begin{array}{l}\text { Measurements including the three mean velocity } \\
\text { components at a few points }\end{array}$ \\
\hline \multicolumn{3}{|l|}{$\begin{array}{l}\text { Flow recirculation in outer-bank } \\
\text { widening }\end{array}$} \\
\hline Nanson (2010) & $\begin{array}{l}\text { Sharply curved natural bend with outer-bank } \\
\text { widening }\end{array}$ & $\begin{array}{l}\text { Measurements including the three mean velocity } \\
\text { components at a few points }\end{array}$ \\
\hline Vietz et al. (2012) & $\begin{array}{l}\text { Sharply curved natural bend with outer-bank } \\
\text { widening }\end{array}$ & $\begin{array}{l}\text { Measurements of velocity magnitude and direction } \\
\text { at a few points }\end{array}$ \\
\hline Schnauder and Sukhodolov (2012) & $\begin{array}{l}\text { Sharply-curved natural bend with outer-bank } \\
\text { widening }\end{array}$ & $\begin{array}{l}\text { Measurements including the three mean velocity } \\
\text { components at a few points }\end{array}$ \\
\hline Parsons (2003) & $\begin{array}{l}\text { Sharply-curved bend on the River Dean with } \\
\text { outer-bank widening }\end{array}$ & $\begin{array}{l}\text { Measurements including the three mean velocity } \\
\text { components at a few points }\end{array}$ \\
\hline \multicolumn{3}{|l|}{ Outer-bank cell of secondary flow } \\
\hline Blanckaert and Graf (2001) & $\begin{array}{l}\text { Sharply-curved laboratory flume with natural-like } \\
\text { bed morphology and smooth vertical banks. }\end{array}$ & $\begin{array}{l}\text { Measurements with high temporal and spatial } \\
\text { resolution, including the three mean velocity }\end{array}$ \\
\hline Blanckaert (2011) & $\begin{array}{l}\text { Sharply-curved laboratory flume with } \\
\text { - Flat immobile bed and smooth vertical banks } \\
\text { for three flow depths } \\
\text { - Flat immobile bed, rough vertical bank and } \\
\text { rough inclined banks }\end{array}$ & $\begin{array}{l}\text { components, the six turbulent stresses, higher-order } \\
\text { turbulent correlations and the turbulent dissipation } \\
\text { rate. }\end{array}$ \\
\hline Blanckaert et al. (in press) & $\begin{array}{l}\text { - Sharply-curved laboratory flume with flat } \\
\text { immobile bed. } \\
\text { - Vertical bank with three different roughness } \\
\text { configurations }\end{array}$ & \\
\hline Jamieson et al. (2010) & $\begin{array}{l}\text { Sharply-curved laboratory flume with smooth } \\
\text { vertical banks and mobile bed }\end{array}$ & $\begin{array}{l}\text { Measurements with high temporal resolution, } \\
\text { including the three mean velocity components } \\
\text { and the six turbulent stresses }\end{array}$ \\
\hline Termini and Piraino (2011) & $\begin{array}{l}\text { Sharply-curved laboratory flume with smooth } \\
\text { vertical banks and mobile bed }\end{array}$ & $\begin{array}{l}\text { Measurements including the three mean velocity } \\
\text { components }\end{array}$ \\
\hline
\end{tabular}

numerical (van Balen et al., 2010a) and experimental (Blanckaert, 2010) investigations. Blanckaert (2011) compared the zone of inner-bank flow separation in experiments with flat immobile bed and mobile bed under similar hydraulic conditions. Results indicated that the shallowing of the inner-bend in the mobile bed experiments favours the onset of inner-bank flow separation. Important remaining knowledge gaps concerning inner-bank flow separation formation and dynamics therefore include: (i) the parameters of influence, (ii) the conditions of occurrence, (iii) the dependence on the streamwise variation of curvature, (iv) the dependence on the roughness and inclination of the inner bank, (v) the mechanisms underlying flow separation, (vi) the interaction of the hydrodynamics with a mobile bed, and (vii) the interaction with flow processes occurring at the outer bank.

Outer-bank cell of secondary flow (vertical around a streamwise axis)

Outer-bank cells of secondary flow occur in the cross-section in the corner formed by the water surface and the outer bank. They rotate with opposite helicity to the centre-region cell of secondary flow, i.e. velocities at the water surface are directed away from the bank. They have been observed in mildly as well as sharply curved bends, and near steep as well as shelving banks. Outer-bank cells have been observed long ago in the laboratory (e.g. Mockmore, 1943; Einstei and Harder, 1954; Rozovskii, 1957) and in the field (e.g. Hey and Thorne, 1975; Bathurst et al., 1977, 1979; Bridge and Jarvis, 1977; Thorne and Hey, 1979; de Vriend and Geldof, 1983; Dietrich and Smith, 1983; Thorne et al., 1985; Markham and Thorne, 1992).

The presence of an outer-bank cell widens the outer-bank boundary layer by repelling maximum streamwise velocities towards the inner edge of the outer-bank cell, which decreases the hydrodynamic forcing on the outer bank. However, its presence also advects high-momentum fluid originating from near the water surface towards the lower part of the outer bank, which tends to increase the hydrodynamic forcing. Based on observations in a natural river, Bathurst et al. (1979) postulated that the first effect is dominant, whereas Blanckaert and Graf (2004) found the second effect to be dominant in a laboratory flume with mobile bed and smooth vertical banks. Blanckaert (2011) argues that the outer-bank cell reduces outer-bank erosion and thus reduces meander migration.

More recent investigations have considerably enhanced knowledge on the outer-bank cell. Experimental research has recently focussed on the dominant generating mechanisms 
(Blanckaert and de Vriend, 2004), such as the effect of the relative curvature $H / R$ (Blanckaert, 2011), the bank roughness (Blanckaert et al., in press), bank inclination (Duarte, 2008; Blanckaert, 2011), and bed morphology (Blanckaert and Graf, 2001; Blanckaert, 2010, 2011; Jamieson et al., 2010; Termini and Piraino, 2011). Complementary numerical investigations performed by van Balen et al. (2009, 2010a, 2010b), Constantinescu et al. (2011) and Kang and Sotiropoulos (2011) have also improved detailed process insight. Despite these recent advances, important knowledge gaps remain, notably the interaction with the presence of inner-bank flow separation and the relation to flow separation at the outer bank.

Flow separation and recirculation at the outer bank (horizontal around a vertical axis)

Flow separation and recirculation at the outer bank has been observed in many natural river bends, e.g. by Hickin (1977) on the Beatton River, by Hickin (1978) on the Squarmisch River, by Hickin and Nanson (1984) on various rivers in western Canada, by Jackson (1992) on the Fall River, by Hodskinson and Ferguson (1998) on the Allt Dubhaig, by Vietz et al. (2012) on the Ovens River, by Schnauder and Sukhodolov (2012) on the Tollense River, by Parsons (2003) on lowland sinuous channels in north England, and in small sinuous channels on intertidal mud flats (Kleinhans et al., 2009).

Flow separation at the outer bank can be driven by an adverse water surface gradient at the outer bank (Blanckaert, 2010). This implies that flow separation at the outer bank mainly occurs in regions of increasing curvature, thus upstream of the bend apex, where transverse tilting of the water surface slope increases and streamwise water surface gradient at the outer bank diminishes. Blanckaert (2010) developed a required condition for the onset of flow separation at the outer bank, $R / B<\left(0.5 \quad C_{f}^{-1} H / B\right)^{1 / 2}$, which suggests that outer-bank flow separation is favoured in smooth and narrow rivers. Here $C_{f}$ is the dimensionless Chézy friction coefficient and $H$ is the overall-averaged flow depth. The onset of outer-bank flow separation can also depend on the inflow conditions, notably inflow asymmetry (Hodskinson and Ferguson, 1998). Furthermore, the occurrence of flow separation at the inner bank that directs the flow towards the outer bank may interact with the development of flow separation at the outer bank.

Channel widening reduces the overall flow velocities and promotes flow separation at the outer bank, but it is not clear if it is a required condition as suggested by Hickin (1977). The earlier mentioned field observations, however, typically occurred at so-called outer-bank benches on sharply-curved bends where the channel widens upstream of the bend apex and has a shallow planar morphology. Their morphological structure typically consists of a basal layer of coarse sediment overlain by organic-rich, fine sediment (Woodyer et al., 1979; Nanson and Page, 1983; Hickin, 1986; Erskine and Livingstone, 1999; Cohen, 2003; Vietz et al., 2012). The basal layer is due to bar formation associated with high-energy flow environments whilst the overlying fine layer is due to sediment deposition in the low-energy flow environment associated with flow separation. Outer-bank benches are thought to protect the outer bank against erosion and to cause erosion at the inner bank upstream from the bend apex (Hickin, 1977, 1978; Page and Nanson, 1982; Markham and Thorne, 1992; Hodskinson and Ferguson, 1998; Vietz et al., 2012). They can, however, also enhance erosion downstream of the bend apex where flow reattaches to the outer bank, as observed on the Tollense River by Schnauder and Sukhodolov (2012). However, in that river, vegetation stabilized the point bar at the inner bank and prevented such erosion.
Notable knowledge gaps with respect to outer-bank flow separation remain and include the overall conditions of occurrence, the control parameters, the influence of the widening geometry, the interaction with the inner-bank flow separation and the outer-bank cell of secondary flow and the influence of the flow-sediment interaction.

\section{Detailed objectives}

The knowledge gaps identified above may largely be attributed to the paucity of detailed experimental data, which is highlighted in Table I. All three processes of flow separation near the channel banks identified earlier have been observed and measured in natural rivers, but with a spatial resolution and an accuracy that are insufficient for a detailed analysis of their hydrodynamic characteristics and a reliable validation of numerical models. High-resolution and high-accuracy laboratory data are not yet available for flow separation and recirculation at the outer bank, and limited to one dataset over a flat immobile bed and one dataset over a mobile bed for flow separation and recirculation at the inner bank (Table I).

This paper reports on a set of laboratory experiments in a schematized configuration intended to isolate and accentuate these near-bank hydrodynamic processes, and to investigate them with an accuracy exceeding that, which could possibly be obtained in a field study. The main objectives of the present paper are: (i) to provide detailed experimental data on the hydrodynamic and morphodynamic characteristics within sharp bends, with focus on the near-bank flow processes; (ii) to investigate the influence of an outer-bank widening on the hydrodynamic characteristics, and in particular on the distinct processes of near-bank flow separation; (iii) to explore the influence of the interaction of the flow with bedload sediment transport on the three processes of near-bank flow separation with a view to understanding their morphological significance, and (iv) to contextualize and discuss the results and to provide guidelines for future research.

The next section details the methods employed to obtain the experimental results. The third section reports and analyses the main experimental observations. The fourth section discusses and contextualizes the results, and provides avenues for future research.

\section{Methods}

\section{Experiment design}

The three processes of flow separation from the banks were investigated in a series of dedicated laboratory flume experiments with a variety of measurement methods. A bespoke flume channel with two bends was created within the Total Environment Simulator (TES) facility at the University of Hull (Figure 1). The constructed channel had fixed walls, a width of $1 \mathrm{~m}$ and a length along the centreline of approximately $15 \mathrm{~m}$. The vertical channel walls were constructed of Plexiglas at high precision and fixed in position within the $12 \mathrm{~m} \times 6 \mathrm{~m}$ basin. As previous research indicated the importance of the ratio of channel width to bend radius, $R / B$ with respect to flow separation, bend radius was varied with radii of $R=1 \mathrm{~m}$ and $R=2 \mathrm{~m}$ in the first and second bend, respectively. Moreover, the second bend was widened in the outer bank region (Figure 1). Experiments were conducted with both immobile-bed and mobile-bed conditions.

Three scaling conditions (Table II) were posed for the immobilebed experiments. First, the Shields number $(\theta)$ was well below critical for motion. Second, the flow was subcritical, that is, 


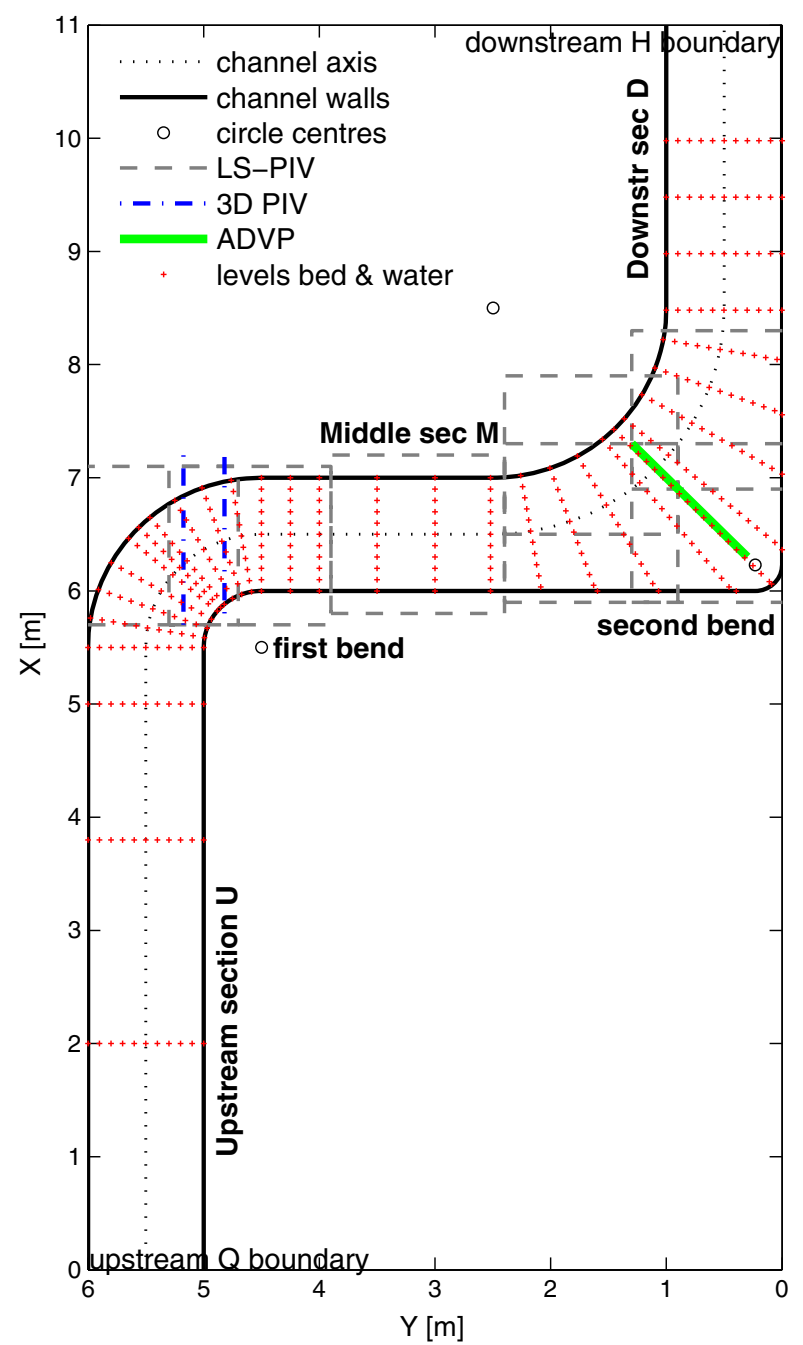

Figure 1. Map of the bespoke flume channel created within the Total Environment Simulator (TES) at Hull University. Flow is from bottom to top (scale in metres). Circular bends are constructed from Perspex. The legend in the insert provides information on the locations of the measurements by means of pressure transducers, Large Scale Surface Particle Image Velocimetry (LS-PIV), three-dimensional Particle Image Velocimetry (3D-PIV), an Acoustic Doppler Velocity Profiler (ADVP) and a manual point gauge (bed and water surface levels).

the Froude number ( $\mathrm{Fr}$ ) was smaller than unity and the flow was in the rough turbulent regime $\left(\operatorname{Re}>2000\right.$ and $\operatorname{Re}_{*}=u k_{s} / v>70$, where $k_{\mathrm{s}}$ is the equivalent sand roughness of the channel bed).
Third, the backwater adaptation length was of the order of the flume length so that the gradient was controllable by the downstream water level, and the flow would thus be quasiuniform. The gravel of the immobile bed was unimodal with $D_{10}=9.7 \mathrm{~mm}, D_{50}=11.8 \mathrm{~mm}$ and $D_{90}=14.5 \mathrm{~mm}$. The longitudinal gradient $(S)$ of the gravel bed was set to $S=2 \times 10^{-3}$. At the upstream end coarser gravel was used to prevent initial inflow erosion and shorten the length of boundary layer adaptation from the flume inlet.

The mobile-bed condition was designed to represent lowenergy lowland rivers with relatively strong banks and a bedload dominated sediment transport regime with dune bedforms (Table II). Bedload transport domination also enables detailed flow measurement which would be very difficult if suspended sediment was the dominant transport mechanism. The mobile bed consisted of unimodal coarse sand with $D_{10}=0.61 \mathrm{~mm}$, $D_{50}=0.76 \mathrm{~mm}$ and $D_{90}=0.94 \mathrm{~mm}$, which was coarse enough to prevent the formation of ripples and promote formation of dunes and bars with limited suspended sediment deposition on the bars. The width/depth ratio was kept small at 8.3 compared to natural channels to promote fixed alternating bars and prevent under-damped bars and 'overshoot' phenomena (Struiksma et al., 1985). The mean gradient of the bed was set to the same as in the immobile-bed experiment at $S=2 \times 10^{-3}$. Transported sediment was collected in a downstream trap and the entire collected volume was recirculated in units of about 9l per 10 minutes to ensure there was no net erosion or deposition through the flume. The bedload dominance and the width/depth ratio represents rivers such as the upper Columbia River (Kleinhans et al., 2012), where strong cohesive banks cause nearly straight channels with occasional sharp bends and a width/depth ratio of 10 for the smaller branches, and exactly damped bars covered by dunes.

Table II provides the basic hydraulic conditions in the experiments and are based on detailed flow measurements in the cross-section $3.8 \mathrm{~m}$ upstream of the first bend. In the immobile-bed experiment, 13 vertical profiles were measured in one half of the (symmetrical cross-section), whereas 15 vertical profiles were measured over the entire width of the cross-section in the mobile-bed experiment. The discharge $(Q)$ was obtained by integration of the measured velocity field. The shear velocity $u_{* \text { bed }}$ within the experiment has been estimated from different methods described by Nezu and Nakagawa (1993): (i) fitting a log law to the measured nearbed velocity profile; (ii) fitting a linear profile to the measured streamwise-vertical turbulent shear stress; (iii) fitting an exponential profile to the measured streamwise turbulent

Table II. Hydraulic and geometric conditions in the here reported experiments and in the similar experiments performed by Blanckaert (2010, 2011).

\begin{tabular}{|c|c|c|c|c|c|c|c|c|c|c|c|c|c|}
\hline Label & $\begin{array}{c}Q \\
\left(\mathrm{ls}^{-1}\right)\end{array}$ & $\begin{array}{c}Q_{\mathrm{s}} \\
\left(\mathrm{kg} \mathrm{s}^{-1} \mathrm{~m}^{-1}\right)\end{array}$ & $\begin{array}{c}H \pm \\
0.005(\mathrm{~m})\end{array}$ & $\begin{array}{c}U \\
\left(\mathrm{~ms}^{-1}\right)\end{array}$ & $\begin{array}{c}\left(\mathrm{g} / C_{\mathrm{f}, \mathrm{bed}}\right)^{1 / 2} \\
\left(\mathrm{~m}^{1 / 2} \mathrm{~s}^{-1}\right)\end{array}$ & $\begin{array}{l}U_{*}, \text { bed } \\
\left(\mathrm{m} \mathrm{s}^{-1}\right)\end{array}$ & $\begin{array}{c}E_{\mathrm{s}} \\
\left(10^{-4}\right)\end{array}$ & $\begin{array}{c}\mathrm{Re} \\
\left(10^{3}\right)\end{array}$ & $\begin{array}{l}\mathrm{Fr} \\
(-)\end{array}$ & $\begin{array}{l}B / H \\
(-)\end{array}$ & $\begin{array}{l}R / B \\
(-)\end{array}$ & $\begin{array}{c}C_{\mathrm{f}, \text { bed }}^{1} H / B \\
(-)\end{array}$ & $\begin{array}{c}\theta \\
(\mathrm{deg})\end{array}$ \\
\hline $\begin{array}{l}\text { Hull_Immobile } \\
\quad \text { (present paper) }\end{array}$ & 117 & - & $0 \cdot 21$ & 0.55 & $40 \cdot 4$ & $0 \cdot 042$ & 10 & 117 & $0 \cdot 38$ & $4 \cdot 7$ & $\begin{array}{l}1 \cdot 0 \text { (first bend) } \\
2 \cdot 0 \text { (second bend) }\end{array}$ & $35 \cdot 8$ & 90 \\
\hline $\begin{array}{l}\text { Hull_Mobile } \\
\quad \text { (present paper) }\end{array}$ & 49 & $0 \cdot 026$ & $0 \cdot 12$ & 0.41 & $22 \cdot 8$ & $0 \cdot 056$ & 17 & 49 & $0 \cdot 37$ & $8 \cdot 3$ & $\begin{array}{l}1 \cdot 0 \text { (first bend) } \\
2 \cdot 0 \text { (second bend) }\end{array}$ & $6 \cdot 4$ & 90 \\
\hline $\begin{array}{l}\text { EPFL_Immobile } \\
\text { (Blanckaert, } \\
2009,2011)\end{array}$ & 89 & - & $0 \cdot 16$ & 0.43 & $38 \cdot 4$ & 0.035 & $8 \cdot 5$ & 69 & $0 \cdot 35$ & $8 \cdot 2$ & $1 \cdot 31$ & $26 \cdot 4$ & 193 \\
\hline $\begin{array}{l}\text { EPFL_Mobile } \\
\text { (Blanckaert, } \\
\text { 2010) }\end{array}$ & 89 & 0.023 & $0 \cdot 14$ & $0 \cdot 49$ & $25 \cdot 5$ & $0 \cdot 060$ & $26 \cdot 7$ & 68 & 0.41 & $9 \cdot 2$ & $1 \cdot 31$ & $8 \cdot 6$ & 193 \\
\hline
\end{tabular}

Note: $Q$ is the flow discharge, $q_{s}$ the sediment discharge, $H$ the flow depth, $U=Q /(B H)$ the overall-averaged velocity, $C_{\mathrm{f}, \text { bed }}$ the dimensionless $C$ hézy friction coefficient for the bed, $u_{*}$,bed the shear velocity on the bed, $E_{\mathrm{s}}$ is the average energy slope based on the measured water and bed elevations, $\operatorname{Re}=U H / N$ is the Reynolds number, $F r=U / \sqrt{g H}$ the Froude number, $B$ the flume width, $R$ the radius of curvature of the bend, $C_{f}^{1} H / B$ a parameter that characterizes a river reach (Blanckaert, 2011) and $\theta$ the opening angle of the bend. 
normal stresses. In agreement with Nezu and Nakagawa's results, estimates according to the different methods vary by about $30 \%$. The dimensionless Chézy friction coefficient of the channel bed is obtained according to the definition: $C_{\mathrm{f}, \text { bed }}=\left(u_{*} \text {, bed } / U\right)^{2}$, where $U=Q /(B H)$ is the overall-averaged velocity.

Field investigations typically parameterize curvature effects by the unique curvature ratio $R / B$, which was identified by Hickin (1974) and Hickin and Nanson (1975) as the dominant control parameter for bend morphodynamics. This ratio tends to infinity for straight rivers, and reaches values less than one for the sharpest bends occurring in nature (see compilation of field data in Crosato, 2008). Although no objective criterion exists, the discriminator between moderately and sharply curved open-channel bends is commonly defined at a value of about $R / B=2$. According to this criterion, both bends in the laboratory flume are sharply curved, with values of one for the sharpest first bend with parallel banks and two for the second bend with the outer-bank widening. According to Blanckaert and de Vriend (2010), however, $C_{\mathrm{f}}^{-1} H / B$ and $B / R$ are the dominant control parameters with respect to the flow redistribution in open-channel bends. The former is a characteristic of a river that accounts for the shallowness and the roughness, whereas the latter parameterizes the curvature of individual bends. Blanckaert (2011) summarizes the value of both control parameters in laboratory flumes and natural meandering rivers. The parameter $C_{\mathrm{f}}^{-1} H / B$ is between six and 10 in most meandering rivers, and tends to decrease with increasing size of the river. Mobile-bed experiments are typically narrower and rougher than natural rivers, leading to similar values of $C_{\mathrm{f}}^{-1} H / B$. In contrast, flat immobile-bed experiments are typically considerably smoother yielding higher values of $C_{\mathrm{f}}^{-1} H / B$. This is confirmed by the values of $C_{\mathrm{f}}^{-1} H / B=6.4$ and $C_{\mathrm{f}}$ ${ }^{1} H / B=35.8$ reported here for the mobile-bed and immobilebed experiments, respectively. Although the global flow redistribution in the immobile-bed experiment is not representative for the behaviour in typical natural alluvial meandering rivers, it is essential to isolate mobile bed effects from bend shape effects on flow separation near the banks.

Obviously, this schematized laboratory open-channel bend cannot be representative of the infinite range of configurations found in nature, which differ in geometric (planform and corresponding evolution of the radius of curvature, width, depth, bank configuration), sedimentological (sediment size and gradation, stratigraphy) and hydraulic (Froude number, Reynolds number, inflow conditions, boundary roughness) characteristics. The reported experiments, however, do not intend to mimic the global hydrodynamic and morphodynamic behaviour of natural open-channel bends. Their objective is to isolate and accentuate the near-bank hydrodynamic processes that occur in curved open-channel reaches, and to investigate them with an accuracy exceeding that, which could possibly be obtained in a field study. We refer to Blanckaert (2011) for a discussion on the effects of the discontinuities in the centreline radius of curvature and the vertical and hydraulically smooth sidewalls.

\section{Measurements}

The flow discharge and water level were controlled and measured throughout each experiment. Flow rates were monitored and controlled by continuous measurement with an electromagnetic flow meter in the pump circuit and a micro-propeller in the flume inlet, placed at $35 \%$ of the water depth above the bed. Seven differential pressure sensors were calibrated in situ and used to record water surface elevation levels along the flume (Figure 1). Average water surface elevations were obtained from 100 measurements at a frequency of $1 \mathrm{~Hz}$. The standard errors of the mean elevation were less than $0.5 \mathrm{~mm}$ at the $99 \%$ confidence level. The offsets of each of the pressure sensors were calibrated at the beginning of the experimental programme by flooding the entire basin and measuring the probe to water surface distances manually.

Water surface levels and bed levels were measured manually by point gauge from beams at 11-17 positions along 32 cross-sections within the flume (Figure 1) with an accuracy of approximately $\pm 2 \mathrm{~mm}$. Data were collected for each experimental condition and at several times during the mobile-bed experiment to record the evolution of the channel bed. All data were post-processed and gridded using bilinear interpolation on a curvilinear grid covering the entire flume.

A range of methodologies was employed to obtain detailed flow measurements within the flume, including Large Scale Surface Particle Image Velocimetry (LS-PIV), three-dimensional Particle Image Velocimetry (3D-PIV) and measurements with an Acoustic Doppler Velocity Profiler (ADVP). Each of these techniques is now briefly outlined.

\section{LS-PIV}

The surface flow structures in both bends and, in the mobile bed case, the straight cross-over reach in between them were measured with LS-PIV at the water surface. This technique has been used successfully in the past to identify the gross flow structures in surface flow (Uijttewaal et al., 2001). White particles of $2 \mathrm{~mm}$ diameter and a density of $900 \mathrm{~kg} \mathrm{~m}^{-3}$ were seeded upstream of the measurement location and occasionally in recirculating zones. Lighting was introduced from downstream to upstream to minimize water surface reflection. The immobile gravel bed was spray-painted black within measurement locations to optimize image contrast. Images were collected perpendicular from above with a 1008x1018 8BPP CCD camera with an exposure time of about four to 20 milliseconds at standard or doubled gain, with the aim of deriving as sharp an image as possible. The field of view was approximately $1.3 \mathrm{~m}$ by $1.3 \mathrm{~m}$ and images were captured for two to three minutes at a rate of $15 \mathrm{~Hz}$. The data were analysed using the dedicated Flow Scout programme (Lekan Owodunni, personal communication 2010). This programme calculates the flow vectors using a standard spectral correlation method to calculate flow velocity and direction in a grid, followed by particle tracking to obtain velocity vectors for each particle, where the average velocity in the interrogation area was used to filter and prevent aliasing whilst allowing variation due to turbulence. This was enhanced with criteria for particle detection on an unevenly lighted background. The vectors for all particle pairs were interpolated on the curvilinear grid by median filtering to produce timeaverage maps of surface flow structure.

\section{D-PIV}

The 3D-PIV measurements were made using a bespoke Dantec submersible system in order to obtain maps of the three components of the velocity vector (see Adrian, 2005, for review). A series of such measurements was obtained in the first bend (Figure 1). The 3D-PIV is a non-intrusive, whole-flow field technique for detailed velocity and turbulence measurement (e.g. Uijttewaal et al., 2001; Hardy et al., 2009). The 3D-PIV system consisted of New Wave Research solo double pulsed Nd:YAG laser (pulse duration 10 nanoseconds, time delay between pulses one millisecond) and two Kodak Megaplus ES1.0 digital cameras (8-bit, 1016×1008 pixel CCD chip). The laser was fitted with beam optics to expand the laser beam into 
a sheet of light, which was normal to the bed surface and parallel to the long side of the flume basin (Figure 1). The paper reports measurements in sections in the first bend at $Y=4.82 \mathrm{~m}$ and $Y=5.175 \mathrm{~m}$ in the immobile-bed and mobile-bed experiments, respectively. These sections are not perpendicular to the channel axis. The width of the light sheet in the lateral direction (perpendicular to the long side of the flume) was about $5 \mathrm{~mm}$. A lens and mirror were used for each camera to focus on the area illuminated by the light sheet from outside the Perspex channel wall. Seeding was tuned to obtain a good tracer particle density for tracking the flow field. The system obtained paired images, which were recorded with a sampling rate of $7.5 \mathrm{~Hz}$ with an imaging area of approximately $500 \mathrm{~mm}$ $250 \mathrm{~mm}$. A $64 \times 32$ pixel interrogation region with $25 \%$ overlap produced a spatial resolution for the calculated vectors of approximately $25 \mathrm{~mm} \times 5 \mathrm{~mm}$. Data were collected over four minutes to provide stationary maps of time-average velocity. Data were collected from about 10 imaging areas across the channel width in the first bend to ensure complete section coverage with at least $50 \%$ overlap between each vector map. Vector maps were combined using a general kriging interpolation method to provide a complete time-average flow field vector map for each section.

\section{ADVP}

An ADVP developed at Ecole Polytechnique Fédérale, Lausanne, Switzerland, was deployed to measure with high spatial and temporal resolution the patterns of the three velocity components in the apex of the second bend and in the cross-section $3.8 \mathrm{~m}$ upstream of the first bend. The working principle of the ADVP has been reported by Lemmin and Rolland (1997), Hurther and Lemmin (1998), Blanckaert and Graf (2001) and Blanckaert and Lemmin (2006). The ADVP was suspended from a horizontal beam above the flume to measure vertical profiles of the threevelocity components. Sequential profile measurements were made at 33 locations across the apex section of the second bend to provide whole cross-section maps of flow properties. One transmitter and four receivers were submerged in a box with a thin mylar foil at the bottom. This foil was submerged just below the water surface, so that the profiler operated through the entire water depth but barely affected the flow. Measurements were performed at a sampling rate of $31 \cdot 25 \mathrm{~Hz}$. Microbubbles of about $70 \mu \mathrm{m}$ were generated by electrolysis as targets for the acoustic pulses emitted by the probes and thus improve the signal to noise ratio of the measurements (Blanckaert and Lemmin, 2006). Blanckaert and de Vriend (2004) and Blanckaert (2010) provide a detailed description and discussion of the measuring techniques, the data treatment procedures and the uncertainty in the data. Measurements in the immobile-bed experiments were made for at least 150 seconds, with an asymmetrically assembled ADVP configuration that allows measuring close to the walls (Blanckaert, 2010). Measurements in the mobile-bed experiments were made with a symmetrically assembled ADVP configuration (Blanckaert, 2010). The highly dynamic channel bed with migrating bedforms of important amplitude $(0.45 \mathrm{H} \pm 0$ $15 \mathrm{H}$, described later) complicated the ADVP measurements in the mobile-bed experiment. The measurement duration was limited to 60 seconds in order to minimize possible influences of the ADVP on the bed, especially in zones of shallow flows where the (relatively small) flow perturbation by the ADVP might trigger increased sediment transport and erosion. The resulting overall patterns discerned from the 60 second averages clearly reveal the flow structure, but does not represent the true timeaverage flow field. Obviously, the 33 vertical profiles are all measured at different times, corresponding to different instantaneous bed morphology configurations.

\section{Results and Interpretation}

Strong non-linear interactions occur between the channel bed morphology, the water surface topography and the flow field. For the sake of clarity, our presentation of results will first describe the morphological features, then the water surface gradients that represent the gravitational driving force on the flow, and subsequently the detailed flow field. We also include two experiments of Blanckaert $(2009,2010,2011)$ in the results section with similar conditions but a different planform geometry, namely a single bend of $193^{\circ}$.

\section{Channel bed morphology}

Figure 2 shows the steady features of the bed morphology at dynamic equilibrium in the mobile-bed experiment. Dynamic equilibrium refers to conditions where the macro-scale features of the bed morphology are stable and where the sediment recirculates through the flume without net erosion or deposition. The bed sediment transport, however, occurs by means of migrating dunes that are superimposed on the steady macroscale bed morphology.

Maximum scour in the first bend occurs about where the projection of the straight inner bank from the inflow reach intersects the outer bank (Figure 2). This observation is consistent with observations by Whiting and Dietrich (1993) in various sinegenerated laboratory meanders and by Blanckaert (2010) in a single-bend laboratory flume. Maximum flow depth in the first bend is about $0.34 \mathrm{~m}=2.78 \mathrm{H}$, which is similar to the maximum flow depth of about $3 \mathrm{H}$ in Blanckaert's experiment (Table II). A depositional sediment bar forms at the inside of the first bend, downstream from the apex, with very shallow flow depths $(0.006 \mathrm{~m}=0.05 \mathrm{H}$, Figure 2). At the apex of the first bend ( $45^{\circ}$ cross-section), before the depositional inner-bank bar begins, the transverse bed profile is approximately linear with the maximum depth near the outer-bank. Scour at the outer-bank increases towards the bend exit, reaching a maximum at the bend exit $\left(90^{\circ}\right.$ cross-section) where the depositional bar at the innerbank also reaches its maximum height and width. This results in a bed profile at the bend exit that is close to bilinear with the maximum measured transverse bed slope of about $32^{\circ}$ which is only slightly less than the angle of repose of the well sorted sand, indicating strong secondary flow. Blanckaert (2010) also observed similar transverse bed profiles and attributed the linear profile to near-bottom inwards velocities over the entire width and the bilinear profile to inwards near-bed velocities over the deepest part of the cross-section (secondary flow) and outwards near-bed velocities over the shallower part. The bed becomes close to flat in the straight cross-over section between the bends (Figure 2). A depositional inner-bend bar forms at the second bend, again positioned downstream from the bend apex. Flow across this bar is only slightly less shallow than in the first bend with a minimum flow depth of $0.011 \mathrm{~m}=0.09 \mathrm{H}$ (Figures 2). The maximum flow depth at the outer bank and maximum height and width of the depositional inner-bend bar in the second bend are slightly upstream of the bend exit $\left(60^{\circ}\right.$ cross-section, Figure 2$)$. However, and similar to the first bend, the maximum scour in the second bend occurs downstream of the apex close to the projection of the straight inner bank from where the straight cross-over reach intersects the outer bank (Figure 2). Interestingly, the maximum bed erosion in the second bend is slightly less than that found in the first bend $(0.31 \mathrm{~m}=2.57 \mathrm{H})$, which indicates that the outer-bank widening hardly reduced the maximum bend scour. In both bends, the maximum flow depth in the mobilebed experiment is greater than in the immobile-bed experiment (Table II). 


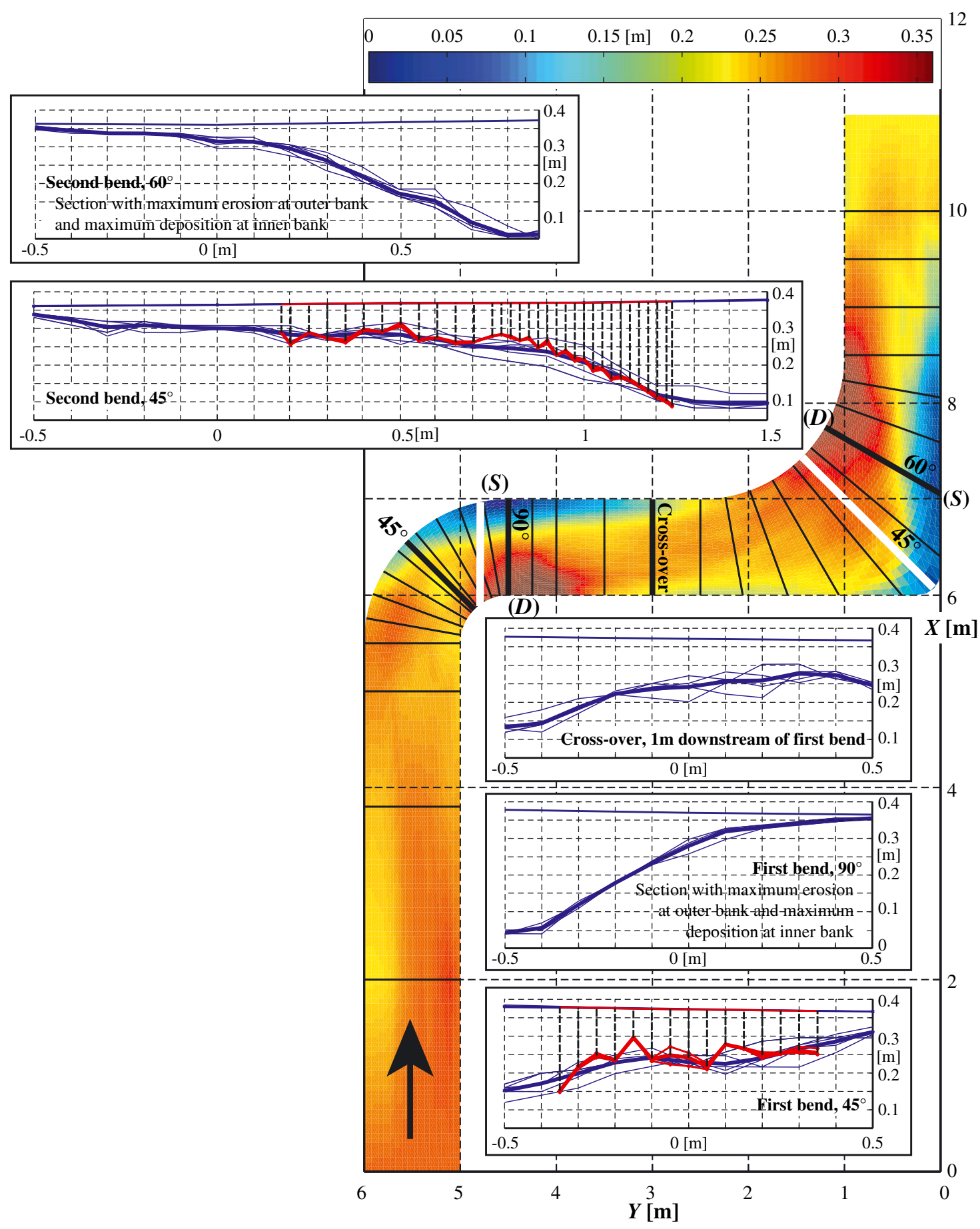

Figure 2. Map of the time-averaged bed morphology based on measurements in the indicated cross-sections with a transverse spacing of $0 \cdot 1 \mathrm{~m}$, $(D)$ and $(S)$ indicate the locations of maximum deposition and scour in the first and second bend. Water surface and bed elevations measured in the indicated cross-sections. The thin blue lines represent measurements of the bed and the water surface elevations by means of a point gauge at five different times after dynamic equilibrium (defined as a stable macro bed morphology with superimposed migrating bedforms) was reached. The thick blue line represents the average bed elevation based on these five measurements. The red lines represent minimum, maximum and average bed elevations based on the ADVP measurements performed in the vertical profiles indicated by means of the dashed black lines. The figures are undistorted. Patterns of the three velocity components in the sections indicated with a white line will be shown in Figure 9 for the first bend, and Figure 11 for the second bend.

The transverse bed slope in alluvial open-channel bends has commonly been parameterized by means of the scour factor $A$ (e.g. Engelund, 1974; Zimmerman and Kennedy, 1978; Odgaard, 1981), defined as:

$$
A=\frac{\partial z_{b}}{\partial n} /\left(\frac{H}{R}\right)
$$

The scour factor is typically within the range 2.5 for sharp bends to six for more gentle bends in natural rivers (Odgaard,
1981; Ikeda et al., 1981; Talmon et al., 1995). According to Blanckaert (2011) and Ottevanger et al. (2012), non-linear hydrodynamic interactions lead to a reduction of the transverse bed slope and the scour factor in sharply-curved bends. Figure 3 shows the evolution around the flume of the scour factor, estimated by fitting a linear profile to the measured transverse bed profiles. The average values of the scour factor in the first and second bends are 1.33 and 2.26, respectively, which implies larger transverse bed slopes than commonly found (table included in Figure 3). The scour factor values suggest that 


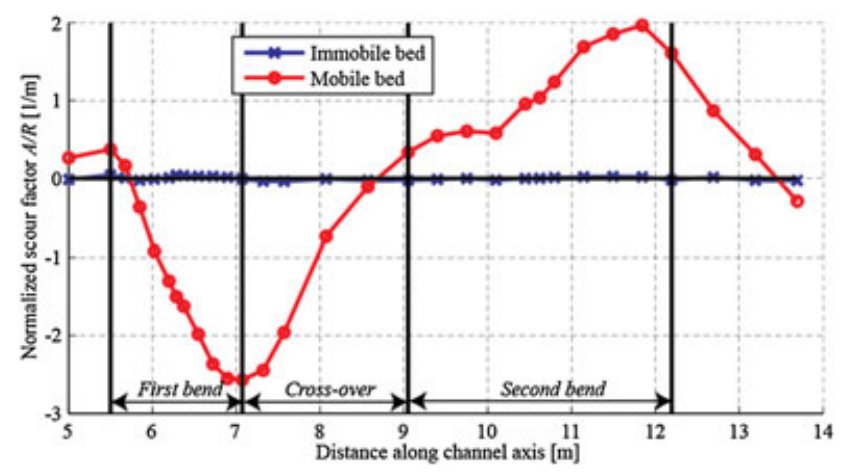

\begin{tabular}{|l|c|c|}
\hline \multirow{2}{*}{ Bend-averaged value of: } & \multicolumn{2}{|c|}{$A=\frac{\partial z_{b}}{\partial n} /\left(\frac{H}{R}\right)$} \\
\cline { 2 - 3 } & Immobile bed & Mobile bed \\
\hline Present experiments: First bend & -0.02 & 1.33 \\
\hline Present experiments: Second bend & 0.00 & 2.26 \\
\hline $\begin{array}{l}\text { EPFL_Immobile and EPFL_Mobile } \\
\text { experiments (Blanckaert 2009, 2010, 2011) }\end{array}$ & 0.00 & 1.96 \\
\hline
\end{tabular}

Figure 3. Evolution along the flume of the normalized transverse bed slope, $A / R$ (Equation 1), in the immobile-bed and mobile-bed experiments. Bend-averaged values are provided in the table, and compared to experimental data of Blanckaert $(2009,2010,2011)$. This figure is available in colour online at wileyonlinelibrary.com/journal/espl

the bed morphology in this laboratory experiment represents well the bed morphology in sharp natural bends. Notably, Figure 3 clearly illustrates that the response of the bed morphology lags considerably behind the planform geometry, since the maximum transverse bed slopes are found near the exit of both bends.

Figure 2 shows the transverse profiles at five cross-sections around the flume measured at five different times after dynamic equilibrium was reached. The considerable differences in bed elevation between these five measured profiles are manifestations of the bedforms associated with the sediment transport. The observed bedforms were very heterogeneous; their height varied across the channel width, crest lines were curved and bifurcated, and they often only covered part of the width of the channel. Bedform crests migrated faster across the inner bends onto the bars, so that dune crests became nearly parallel, rather than perpendicular, to the main flow in the straight section following the first bend. In the second bend, dunes migrated into the widening region, following the direction of flow towards the side wall of the flume. Strong vertical flow near the outer bank, concentrated in the outer-bank cell, scoured the bed near to the bank deeply and sediment was transported mainly in suspension by the dunes into the scour. Dune amplitude was $2.9 \mathrm{~cm} \pm 2 \mathrm{~cm}$, which corresponds to about $0 \cdot 25 \mathrm{H} \pm 0.15 \mathrm{H}$, and their celerity was of the order of $1 \mathrm{~mm} \mathrm{~s}^{-1}$. Dunes with such pronounced amplitudes and variations in crest direction can be expected to affect considerably the hydrodynamics as well as the local flow resistance.

\section{Water surface topography}

Flow in the immobile-bed and mobile-bed experiments is quasiuniform, as indicated by the cross-sectional averaged flow depth that shows little variation around the flume (Figure 4). The crosssectional averaged streamwise energy gradients are -0.0010 and -0.0017 in the immobile-bed and mobile-bed experiments, respectively.

Flow in open-channel bends is largely driven by streamwise water surface gradients (or equivalent energy gradients). In a

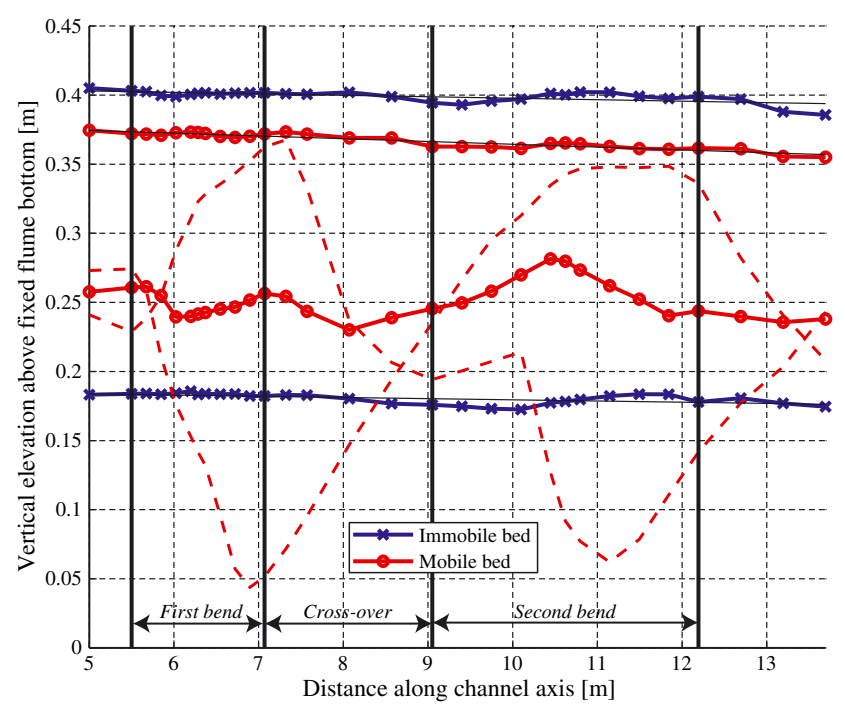

Figure 4. Evolution along the flume of the cross-sectional averaged bed and water surface levels in the immobile-bed and mobile-bed experiments. The dashed lines without labels represent the bed elevation at the left and right bank in the mobile-bed experiment. This figure is available in colour online at wileyonlinelibrary.com/journal/espl

comparable laboratory experiment in a sharply-curved openchannel bend with mobile bed, Blanckaert's (2010) term-byterm analysis of the momentum equation indicated that streamwise water surface gradients are of dominant importance in zones of inner-bank flow separation and in zones of adverse pressure gradients at the outer bank. In both the here-reported immobile-bed and mobile-bed configurations, adverse water surface gradients occur in both bends at the outer bank near the bend apex, and at the inner bank just downstream of the bend exit (not shown). These adverse water surface gradients are closely related to the curvature-induced transverse tilting of the water surface (also called superelevation). A first approximation of the water surface gradient at the centreline and the transverse tilting of the water surface can be estimated as:

$$
\begin{gathered}
\frac{\partial z_{s}(n=0)}{\partial s}=-S_{s}=-C_{f} \frac{U^{2}}{g H}=-C_{f} F r^{2} \\
\frac{\partial z_{s}}{\partial n}=\alpha_{\text {superelevation }} \frac{U^{2}}{g H} \frac{H}{R}=\alpha_{\text {superelevation }} F r^{2} \frac{H}{R}
\end{gathered}
$$

The water surface elevation is indicated by $z_{\mathrm{s}}$ and $S_{\mathrm{s}}$ represents the streamwise water surface gradient. The second relation is based on the depth-averaged transverse momentum equation reduced to its two dominant terms (Chow, 1959). The factor $\alpha_{\text {superelevation }}$ represents the normalized transverse tilting of the water surface. The centreline radius of curvature $R$ varies in streamwise direction, leading to:

$$
\begin{aligned}
\frac{\partial z_{s}}{\partial s} & =-C_{f} F r^{2}+\alpha_{\text {superelevation }} F r^{2} \frac{\partial}{\partial s}\left(\frac{H}{R}\right) n \\
& =-C_{f} F r^{2}\left[1+\alpha_{\text {superelevation }} \frac{H}{C_{f} B} \frac{\partial}{\partial s}\left(\frac{B}{R}\right) n\right]
\end{aligned}
$$

The second term between the square brackets represents the effect of the curvature-induced transverse tilting of the water surface on the streamwise water surface gradient. Blanckaert (2011) summarizes values of $C_{f}^{-1} H / B$ for some natural meandering rivers, which are typically in the range between five and 10 . This implies that the second term in between square brackets is of the order one in sharp bends, characterized by values of $B / R$ smaller 


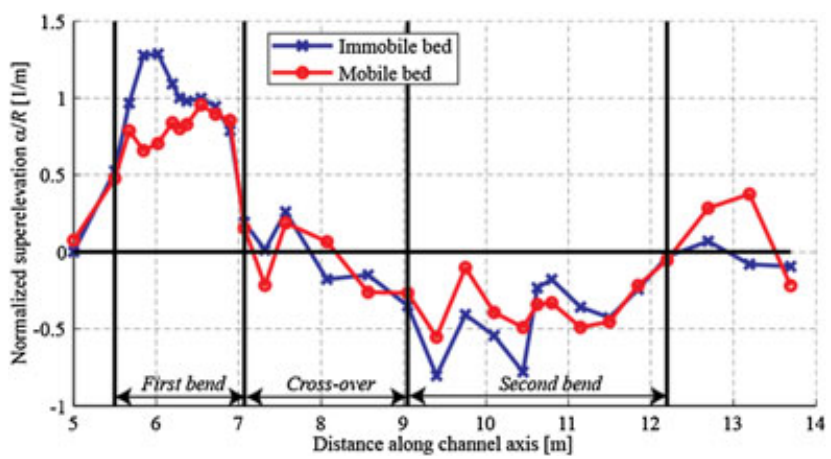

\begin{tabular}{|l|c|c|}
\hline \multirow{2}{*}{ Bend-averaged value of: } & \multicolumn{2}{|c|}{$\alpha_{\text {superelevation }}=\frac{\partial z_{s}}{\partial n} /\left(\operatorname{Fr}^{2} \frac{H}{R}\right)$} \\
\cline { 2 - 3 } & Immobile bed & Mobile bed \\
\hline Present experiments: First bend & 0.91 & 0.72 \\
\hline Present experiments: Second bend & 0.79 & 0.67 \\
\hline $\begin{array}{l}\text { EPFL_Immobile and EPFL_Mobile } \\
\text { experiments (Blanckaert 2009, 2010, 2011) }\end{array}$ & 1.03 & 0.64 \\
\hline
\end{tabular}

Figure 5. Evolution along the flume of the normalized transverse water surface slope, $\alpha_{\text {superelevation }} / R$ (Equation 3 ), in the immobile-bed and mobile-bed experiments. Bend-averaged values are provided in the table, and compared to experimental data of Blanckaert $(2009,2011)$. This figure is available in colour online at wileyonlinelibrary.com/journal/espl

than about two. In such bends, the streamwise water surface gradient is about doubled at the inner/outer bank and regions of adverse pressure gradient may occur at the outer/inner bank in regions of increasing/decreasing curvature. These considerations highlight the importance of the transverse tilting of the water surface with respect to the flow redistribution in sharp openchannel bends and with respect to the onset of flow separation at the inner and outer banks.

Figure 5 compares the evolution around the flume of the normalized transverse tilting of the water surface, $\alpha_{\text {superelevation }} / R$ and the associated table summarizes the average values of $\alpha_{\text {superelevation }}$ in both bends. The interaction between the flow and the mobile bed morphology reduces the transverse tilting of the water surface by about $20 \%$. Blanckaert $(2009,2011)$ found a similar, but larger, reduction in the transverse water surface elevation due to flow-sediment interactions (see table included in Figure 5). The experimental data furthermore indicate that an outer-bank widening reduces the transverse tilting of the water surface. The reduction of the transverse tilting of the water surface due to the flow and sediment interaction or due to the outer-bank widening opposes the onset of outer-bank flow separation, but favours the onset of inner-bank flow separation in regions of increasing curvature.

\section{Surface flow velocities}

The pattern of velocity vectors at the water surface measured by means of LS-PIV (Figures 6 and 7) clearly reveals, as expected, that flow redistribution and flow separation from the boundaries are induced by curvature changes in both experiments. At the entrance of both bends, the locus of highest velocities is impelled towards the inner bank, whereas it is impelled towards the outer bank at the exit of both bends.

In the first bend, just downstream of the bend entrance, the locus of highest velocities starts migrating outwards and separates from the inner bank. A zone of retarded flow occupies the region in between the inner bank and the core of highest velocities. The internal shear layer at the interface between the low and high velocity zones remains very distinct throughout the bend. In the immobile-bed experiment, no flow recirculation occurs at the water surface in the low velocity zone. Sediment is, however, likely to accumulate in this zone as shown by the bar formation in the mobile-bed experiment. With sufficient accumulation of sediment, topographic steering of the flow around the shallow zones into the deep zones

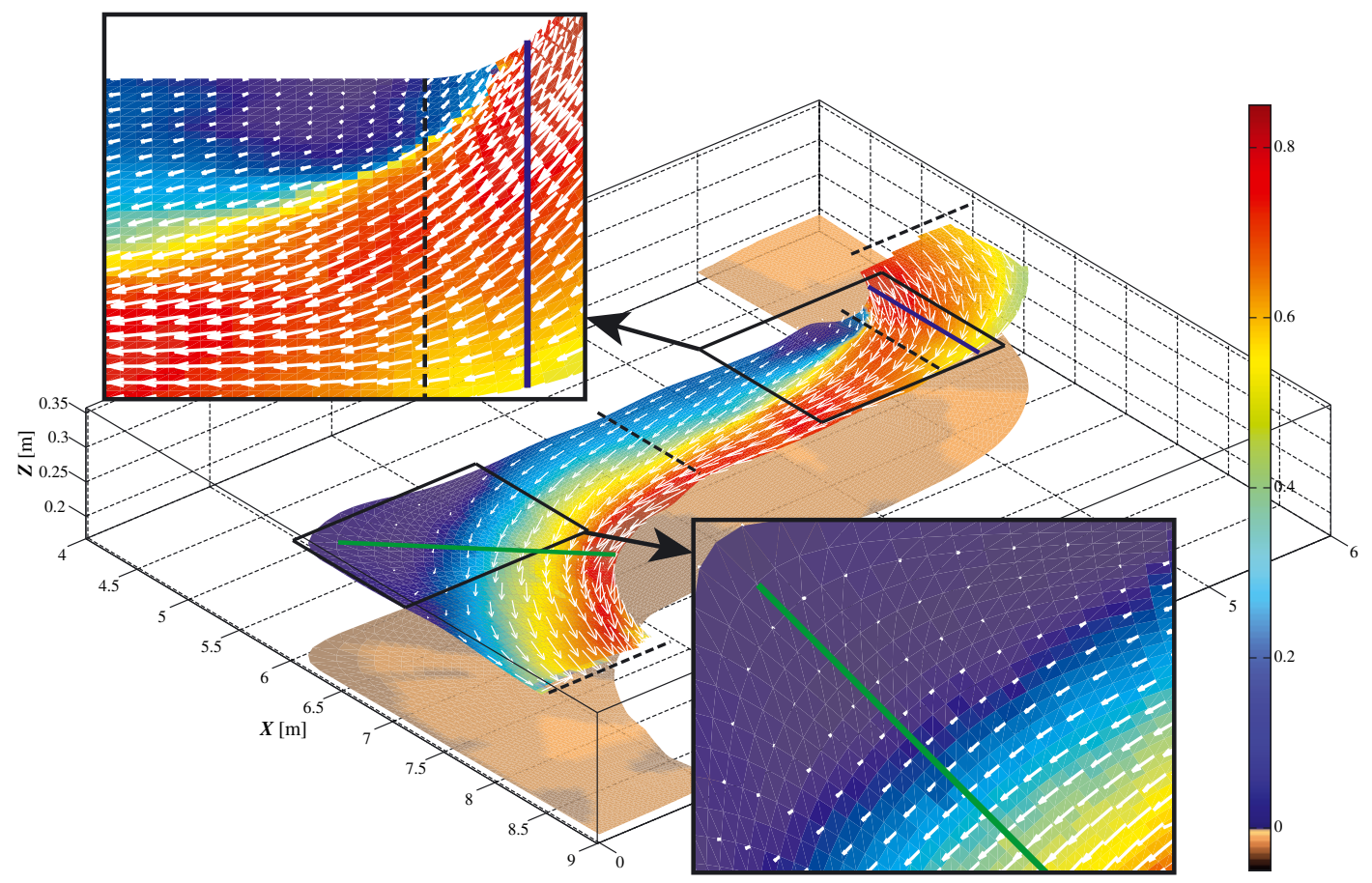

Figure 6. Velocity vector at the water surface obtained by means of LS-PIV measurements in the immobile-bed experiment. The inserts show exploded views of the velocity vectors in the first and second bends. The dashed black lines indicate the entrance and exit of the first and second bend. The three-dimensional flow patterns in the section at $Y=4.82 \mathrm{~m}$ in the first (thick blue line) and in the apex of the second bend (thick green line) are shown in Figures 8 and 10, respectively. 


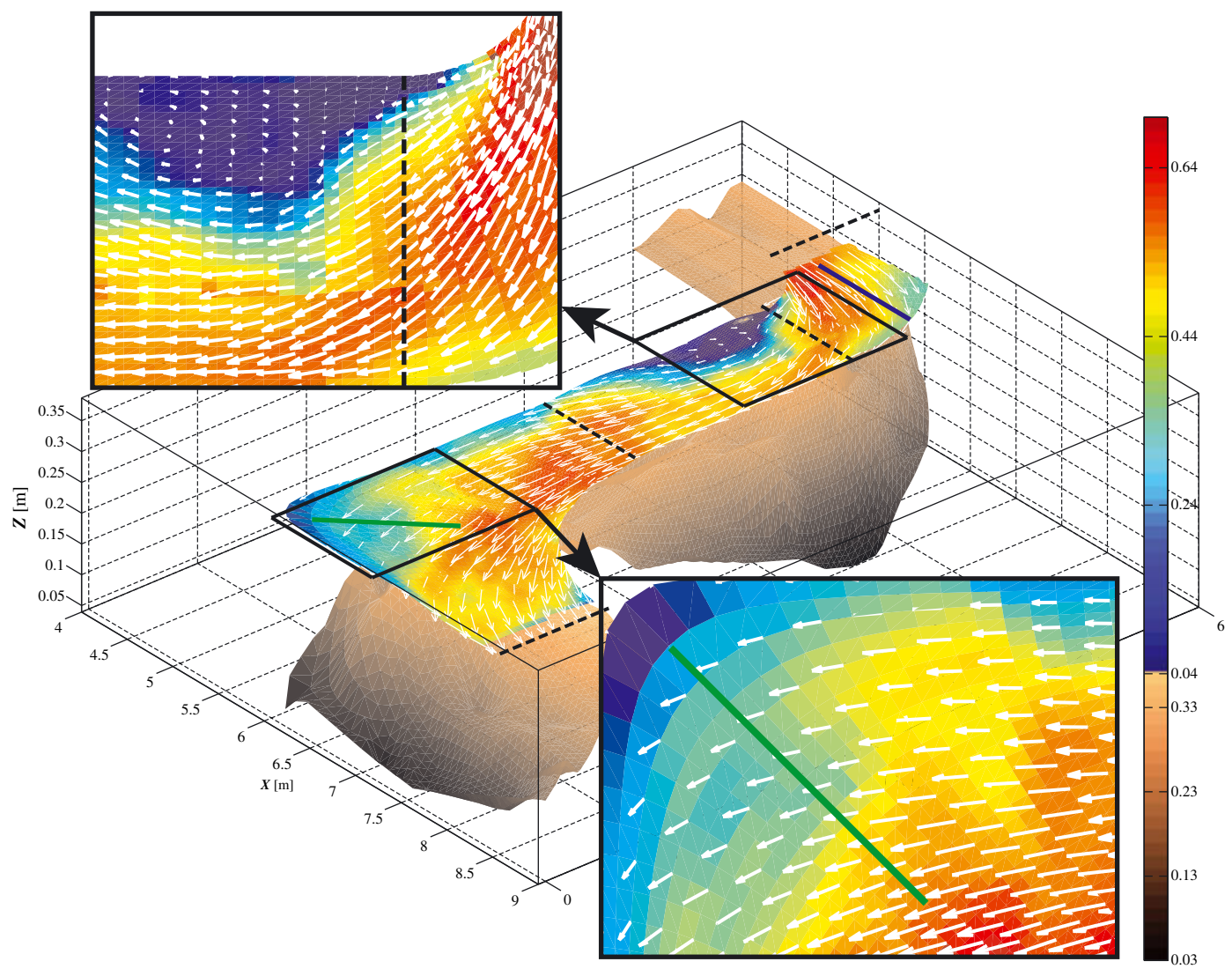

Figure 7. Velocity vector at the water surface obtained by means of LS-PIV measurements in the mobile-bed experiment. The inserts show exploded view of the velocity vectors in the first and second bends. The dashed black lines indicate the entrance and exit of the first and second bend. The three-dimensional flow patterns in the section at $Y=5.175 \mathrm{~m}$ in the first (thick blue line) and in the apex of the second bend (thick green line) are shown in Figures 8 and 10, respectively.

amplifies the outwards velocity redistribution, deforms the internal shear layer, and leads to the formation of recirculation over the inner-bend bar (Figure 7). In both the immobile-bed and mobile-bed experiments, the effective width of the crosssection is reduced and the flow is essentially restricted to the outer part of the cross-section, and collides obliquely with the outer bank, where it contributes to the formation of the deep scour pool. These flow patterns are similar to observations by Bagnold (1960) and Leeder and Bridges (1975), whereas the morphological implications conform to the observations by Frothingham and Rhoads (2003), Ferguson et al. (2003) and Blanckaert (2010).

In the straight cross-over section between both bends, topographic steering of the flow causes considerable differences in the flow redistribution between the immobile-bed and mobile-bed configurations. The recovery towards a quasi-flat bed in the mobile-bed experiment is accompanied by a homogenization of the velocity distribution over the width of the channel. This is in contrast to the immobilebed experiment, where the locus of highest velocities remains attached to the left bank. This leads to considerably different flow distributions at the entrance to the second bend, which are relevant with respect to the occurrence of flow separation at the inner bank and the flow characteristics through the second bend.

In the immobile-bed configuration, the high velocities at the inner bank are further accelerated at the entry of the second bend due to the change in curvature (cf. Equation 4). Due to mass conservation, this causes an inwards mass transport that opposes the onset of flow separation at the inner bank. The majority of the discharge is conveyed near the inner bank, and the outer-bank widening only conveys a marginal part of the discharge. As a result, the outer-bank widening hardly affects the hydrodynamic behaviour of the second bend in the immobile-bed configuration. The outer-bank widening merely constitutes a kind of dead-water zone, containing a weak horizontal recirculation eddy (e.g. Page and Nanson, 1982; Hickin 1986; Parsons 2003).

The interaction between the flow and the sediment transport considerably affects the hydrodynamic characteristics in the second bend. The shallowing/deepening of the flow in the inner/outer part of the second bend and the widening cause an outwards mass transport, which favours the onset of flow separation at the inner bank. The measured surface velocity patterns suggest that the flow is near the onset of innerbank flow separation in the mobile-bed experiment. Inertia enhances the tendency of the flow to follow a straight path parallel to the bank of the outer-bank widening and to collide with the outer bank downstream of the bend apex near the location where the maximum scour occurs. When compared to the immobile-bed configuration, the flow distribution is less heterogeneous over the width in the mobile-bed configuration and the outer-bank widening over the mobile bed conveys a non-negligible part of the flow discharge. Contrary to the immobile-bed configuration, the pattern of surface velocities does not reveal any flow recirculation in the outer-bank widening.

\section{Three-dimensional flow features}

\section{First bend}

Measurements performed by means of 3D-PIV are shown (Figures 8 and 9) in the sections located at $Y=4.820 \mathrm{~m}$ and 


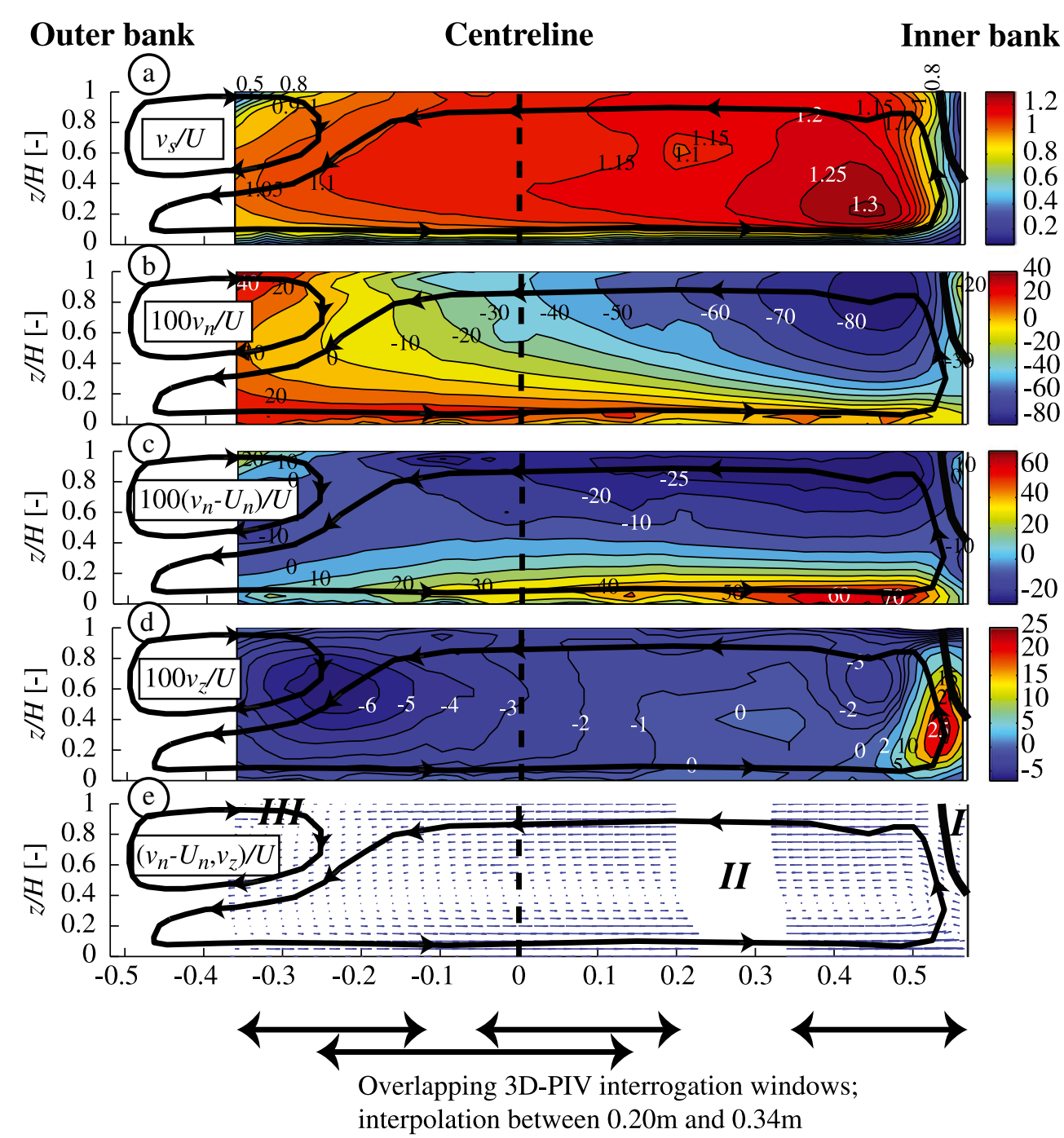

Figure 8. Time-averaged flow in the first bend in the section at $Y=4.82 \mathrm{~m}$ (see Figures 1 and 6) with immobile-bed configuration. (a) Isoline pattern of the normalized streamwise (parallel to the channel axis) velocity, $v_{s} / U$ (b) Isoline pattern of the normalized transverse (perpendicular to the channel axis) velocity, $100 v_{n} U$. (c) Isoline pattern of the circulatory part of the normalized transverse velocity, $100\left(v_{n}-U_{n}\right) / U(\mathrm{~d})$ Isoline pattern of the normalized vertical velocity, $100 v_{z} / U$. (e) Normalized vector presentation of the circulatory part of the secondary flow $\left(v_{n}-U_{n}, v_{z}\right) / U$. Measurements were performed by means of 3D-PIV on the overlapping interrogation windows indicated in the figure. Schematic representation of the secondary flow pattern and near bank flow processes: (I) zone of inner-bank flow separation; (II) centre-region cell of secondary flow; (III) outer-bank cell of secondary flow. Undistorted figures.

$Y=5.175 \mathrm{~m}$ in the immobile-bed and mobile-bed experiments, respectively (cf. Figure 1 ). In order to facilitate comparison to the second bend, however, velocity components are shown parallel $\left(v_{\mathrm{s}}\right)$ and perpendicular $\left(v_{n}, v_{z}\right)$ to the channel axis (cf. Figures 1, 6 and 7). In the immobile-bed configuration, the low streamwise velocities, $v_{\mathrm{s}}$ (Figure 8a) near the inner bank reveal the zone of reduced streamwise velocity. It narrows from the water surface towards the bed and is separated from the main flow body by an inclined shear layer. The low velocities near the inner-bank promote the settlement of sediment and the formation of the depositional sediment bar. Another zone of relatively low streamwise velocities occurs near the outer bank. The core of highest velocities is still situated in the inner half of the measured section. Advective momentum transport by the secondary flow (Figure 8a-c) contributes to the velocity redistribution in the bend. In the immobile-bed configuration, a centre-region cell of secondary flow occupies the major part of the cross-section (Figure 8). A counterrotating secondary flow cell occurs near the outer bank. At the junction of this outer-bank cell and the centreregion cell at $n=-0.2 \mathrm{~m}$, considerable vertical velocities are conveying streamwise momentum downwards, which impinges on the outer bank and the channel bed and thereby promotes scour.

The flow-sediment interaction considerably modifies the flow patterns in the first bend, especially in the zone of innerbank flow separation and near the outer bank. As described in the previous section, topographic steering of the flow causes the maximum streamwise velocities to occur over the deepest outer part of the cross-section (Figure 9). The centre-region cell of secondary flow is restricted to the scour pool zone in the outer half of the cross-section. No outer-bank cell of secondary flow is discernable in the corner formed by the water surface and the outer bank. This can be attributed to the pronounced outwards topographic steering that directs the flow towards the outer bank and impedes the development of an outer-bank cell. Vertical velocities that impinge on the channel bed occur near the outer bank. Streamwise velocities are relatively low and uniform over the flow depth in the zone of inner-bank flow recirculation (Figures 7 and 9). Transverse velocities over the shallow inner part of the cross-section do not lead to the formation of a secondary flow cell. They are conditioned by topographic steering and are outwards directed (cf. Figures 7 and 9) in the measured cross-section. 

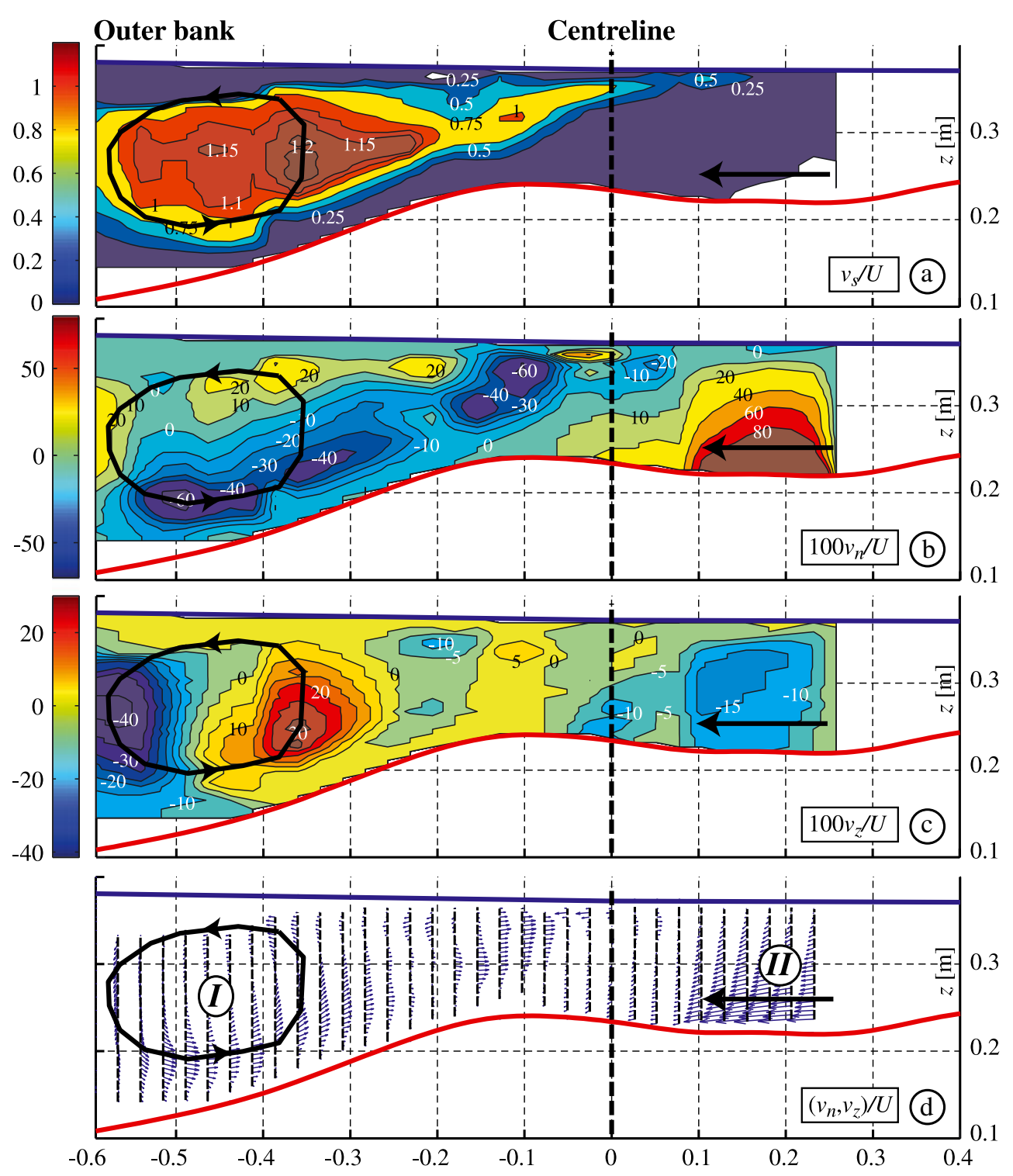

Figure 9. Time-averaged flow in the first bend in the section at $Y=5.175 \mathrm{~m}$ (see Figures 1, 2 and 7) with mobile-bed configuration. (a) Isoline pattern of the normalized streamwise (parallel to the channel axis) velocity, $v_{\mathrm{s}} / U(\mathrm{~b})$ Isoline pattern of the normalized transverse (perpendicular to the channel axis) velocity, $100 v_{n} U$. (c) Isoline pattern of the normalized vertical velocity, $100 v_{z} / U$. (d) Normalized vector presentation of the secondary flow $\left(v_{n}, v_{z}\right) / U$. Measurements were performed by means of 3D-PIV. Schematic representation of the secondary flow pattern and near bank flow processes: (I) centre-region cell of secondary flow; (II) Outwards mass transport over the point bar at the inner side of the bend. The thick red line represents the average bed elevation at dynamic equilibrium based on point gauge measurements (see Figure 2). Undistorted figures.

Second bend

Integration of the streamwise velocity pattern in the immobilebed experiment (Figure 10a) shows that the one metre wide inner part of the bend conveys $97.3 \%$ of the discharge, indicating that transverse flow expansion in the widening region is negligible. The recirculating flow in the outer-bank widening (Figure 6) is rather uniform over the flow depth (Figure 10). Weak cross-stream velocities do not show an organized pattern and no outer-bank cell can be identified. The recirculating flow in the outer-bank widening has a mass flux that is estimated at about $11 \mathrm{I} \mathrm{s}^{-1}$, which corresponds to about $10 \%$ of the discharge. These observations indicate that the second bend mainly consists of two distinct zones: an inner part that behaves as a constant-width bend, and an outer bank widening with weak horizontal flow recirculation. The shear at the interface between both zones is generally weak (cf. weak velocity gradients in Figure 10) and does not lead to significant generation of turbulence (not shown). Hydrodynamic differences between the first and second bends in the immobile-bed configuration are therefore not due to the outer-bank widening, but rather to the different inflow conditions and the different radius of curvature. A small core of retarded streamwise velocities (Figure 10a) and relatively strong outwards transverse velocities (Figure 10b) occurs in the upper part of the water column near the inner bank, which suggest that the main flow body is near the critical condition required for separation from the inner bank. It is weaker than in the first bend, however, which can be attributed to two causes. First, the second bend is less sharply curved than the first bend. Second, the global flow redistribution advects the remnant centre-region cell of secondary flow from the first bend towards the inner bank of the second bend. The inwards directed near-surface velocities in this secondary flow cell oppose the onset of inner-bank flow separation. A centre-region cell of secondary flow induced by the curvature of the second bend develops from the bed upwards. This can be explained by the imbalance between the outwards centrifugal force and the inwards pressure force that is largest at the bed. The cell spans almost the entire flow depth in the centre of this widening cross-section. But the remnant centre-region cell from the first bend still sits on top of it at the inner side of the crosssection. This two-cell pattern is clearly revealed by the patterns 
Inner bank

1.5
1
0.5
0

20
10
0
-10
-20

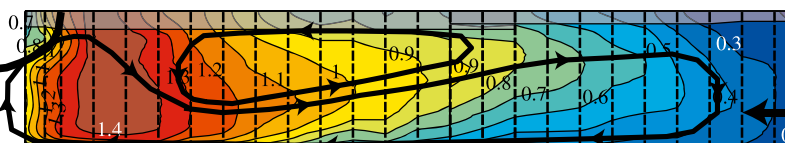

Outer bank

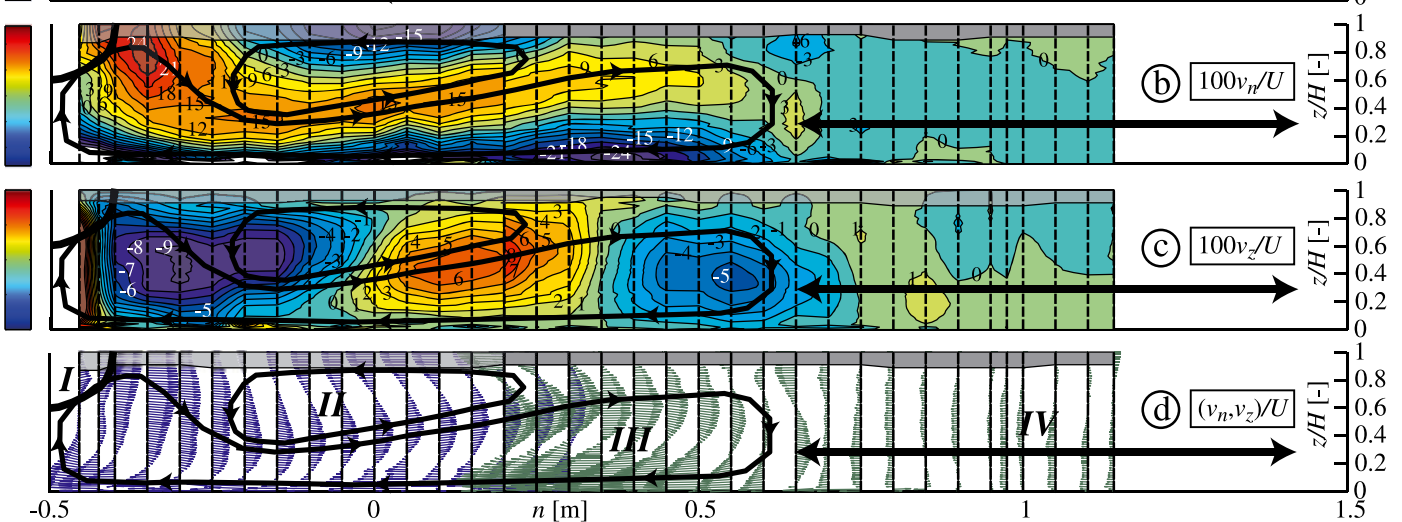

Figure 10. Time-averaged flow in the apex of the second bend (see Figures 1 and 6) with immobile-bed configuration. (a) Isoline pattern of the normalized streamwise (parallel to the channel axis) velocity, $v_{s} / U$. (b) Isoline pattern of the normalized transverse (perpendicular to the channel centerline) velocity, $100 v_{n} U$. (c) Isoline pattern of the normalized vertical velocity, $100 v_{z} / U$. (d) Normalized vector presentation of the secondary flow $\left(v_{n}, v_{z}\right) / U$. Measurements were performed on two measuring grids that overlap in the region $n=-0 \cdot 2$ to $n=-0 \cdot 3$. The shaded areas indicate regions where the flow measurements are perturbed by the ADVP housing that touches the water surface (more details in Blanckaert, 2010). Schematic representation of the secondary flow pattern and near bank flow processes: (I) zone of inner-bank flow separation; (II) remnant centre-region cell of secondary flow from upstream bend; (III) centre-region cell of secondary flow; (IV) zone of horizontal outer-bank recirculation. Undistorted figures.

of the transverse velocity (Figure 10b), the vertical velocity (Figure 10c) and the vector pattern of the secondary flow (Figure 10d).

The flow-sediment interaction fundamentally modifies the flow processes in the second bend. Contrary to the immobilebed configuration, the flow expands and occupies the entire width of the widening cross-section in the mobile-bed configuration (Figure 11a). As already mentioned earlier, the outerbank widening in the mobile-bed configuration conveys a non-negligible part of the discharge. The major part of the discharge is conveyed in the central part of the widening cross-section. Integration of the measured velocity patterns
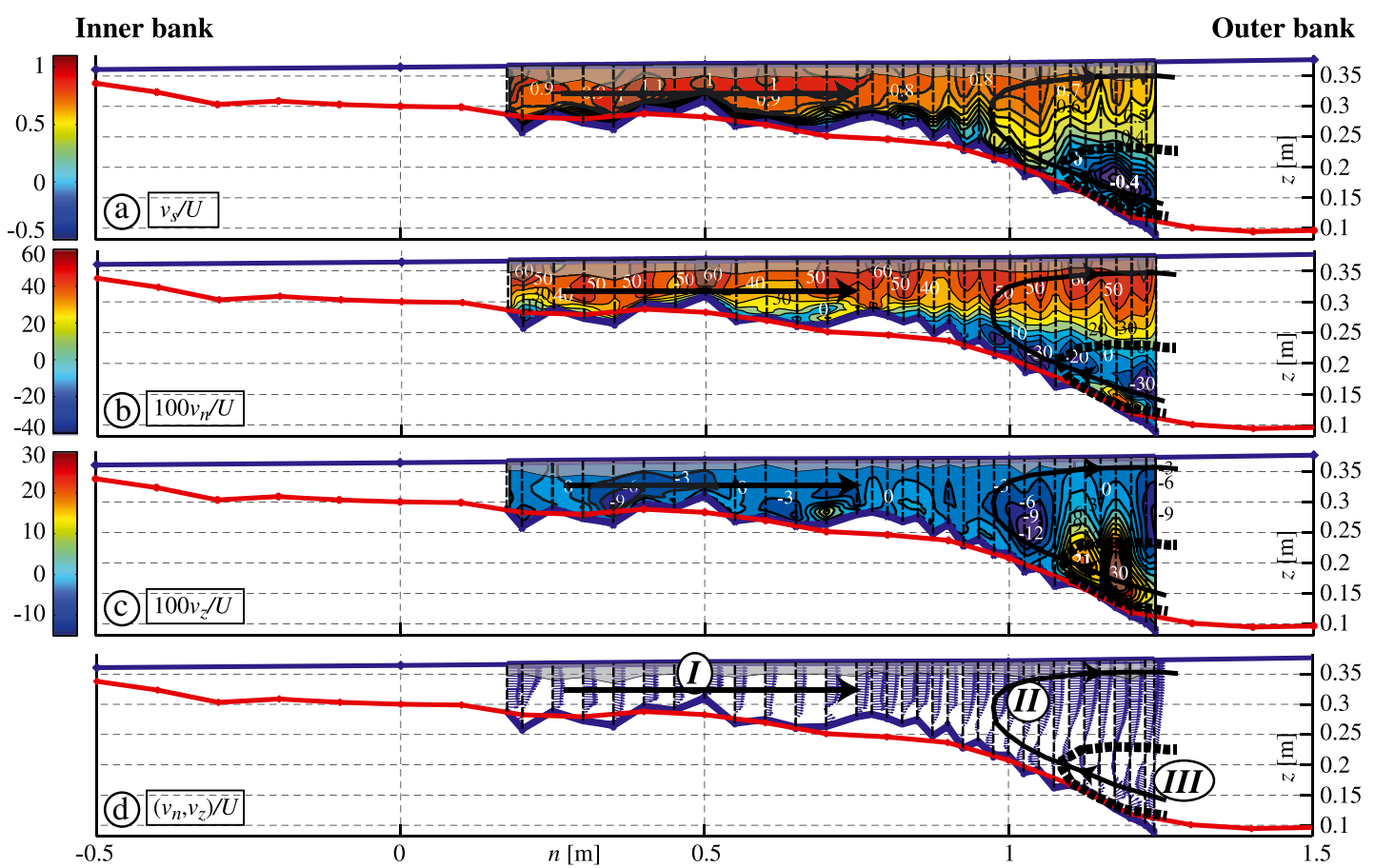

Figure 11. Time-averaged flow in the apex of the second bend (see Figures 1, 2 and 7) with mobile-bed configuration. (a) Isoline pattern of the normalized streamwise (parallel to the channel centerline) velocity, $v_{\mathrm{s}} / U$. (b) Isoline pattern of the normalized transverse (perpendicular to the channel centerline) velocity, $100 v_{n} / U$. (c) Isoline pattern of the normalized vertical velocity, $100 v_{z} / U$. (d) Normalized vector presentation of the secondary flow $\left(v_{n}, v_{z}\right) / U$. The shaded areas indicate regions where the flow measurements are perturbed by the ADVP housing that touches the water surface (more details in Blanckaert, 2010). Schematic representation of the secondary flow pattern and near bank flow processes: (I) outwards mass transport over the shallow zone induced by topographic steering; (II) secondary flow in the outer-bank widening; (III) return current in lower part of the flow depth in the outer-bank widening. The thick red line represents the average bed elevation at dynamic equilibrium based on point gauge measurements (see Figure 2). The thick blue line represents the average bed elevation at dynamic equilibrium based on ADVP measurements (see Figure 2). Undistorted figures. 
indicates that $66 \%$ of the discharge flows through the measured portion of the cross-section. The flow pattern in the widening cross-section resembles typical flow patterns in sharp mobilebed open-channel bends of constant width. The flow is rather uniform over the flow depth over the shallow inner part of the cross-section. Its outwards direction can be explained by three combined effects of which we cannot estimate the exact contributions: (i) topographic steering, as the flow encounters decreasing/increasing depths in the inner/outer part of the cross-section (Figures 2 and 7); (ii) the inertial tendency of the flow to follow a straight path parallel to the bank of the outerbank widening and to collide with the outer bank downstream of the bend apex; (iii) the widening geometry. The experimental set-up did not allow measurement of the velocity patterns in the zone of inner-bank flow separation (Figure 7). Maximum velocities do not occur in the deepest outer part of the crosssection, but in the shallow central part of the cross-section. This is similar to observations by Blanckaert (2010) in a constantwidth bend. Similar to constant-width bends, the centre-region cell of secondary flow is restricted to the deepest outer part of the cross-section. Contrary to the immobile-bed configuration, no remnant centre-region cell from the first bend is discernable. This can be attributed to several effects. The adaptation length of the centre-region cell of secondary flow scales with $C_{\mathrm{f}}^{-1} \mathrm{H}$ (e.g. Rozovskii, 1957; de Vriend, 1981; Johannesson and Parker, 1989). The shallower flow and the rougher bed in the mobile-bed experiment reduce the effect of remnant cells from the upstream bend. This is in line with fieldwork on large rivers with high relative roughness (e.g. Parsons et al., 2007) and a numerical study by Kang and Sotiropoulos (2011) that shows that relatively shallow and rough cross-over reaches between successive bends tend to homogenize the flow and to eliminate upstream effects. Some important differences exist between the flow in the widening bend and in constant-width bends over mobile beds. The flow pattern in the deepest part of the cross-section is more complicated in the widening bend than in constant-width bends. The detailed measurements in the cross-section reveal that a return current exists in the outerbank widening which is located below the water surface and was therefore not revealed by the LS-PIV measurements at the water surface (Figure 7).

\section{Discussion}

The experiments in an idealized laboratory set-up were successful in reproducing, isolating, and accentuating the distinct processes of near-bank flow separation that have been observed in sharply-curved natural open-channel bends. The present section discusses the relevance and generality of the results, especially with respect to the research objectives.

Figure 12 conceptualizes the experimental observations and the dominant hydrodynamic processes in sharp open-channel bends. Figure 12a shows the processes in the canonical case of a sharply-curved open-channel bend with a constant width and a flat immobile bed. Figure $12 \mathrm{~b}-\mathrm{d}$ conceptualize the effect on the near-bank flow processes of the interaction of the flow with bedload sediment transport and outer-bank widening. Table III summarizes the inflow conditions, changes in curvature, inertia and secondary flow as the dominant processes. In order to generalize the results, Table III also discusses the influence of these dominant processes on the flow separation near the inner bank, the flow separation near the outer bank and the outer-bank cell of secondary flow, and identifies the key parameters that control these processes.

This paper provided the first detailed experimental data on three distinct processes of near-bank flow separation. This is an essential step that will allow further insight by means of a combination of field experiments, laboratory experiments and numerical modelling. In this approach, the dominant processes
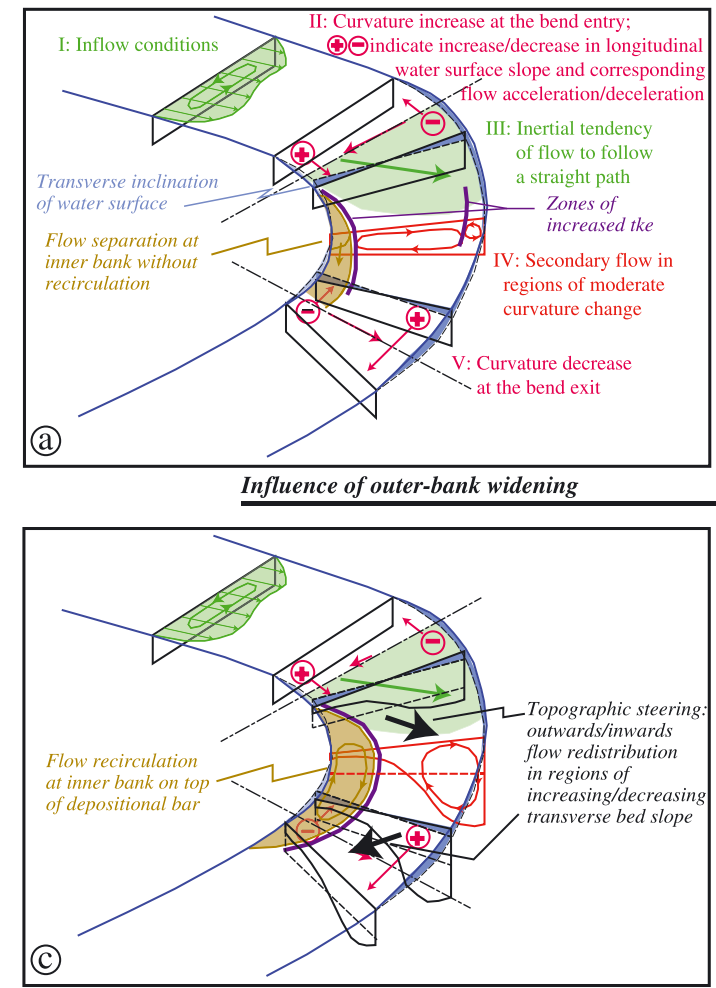
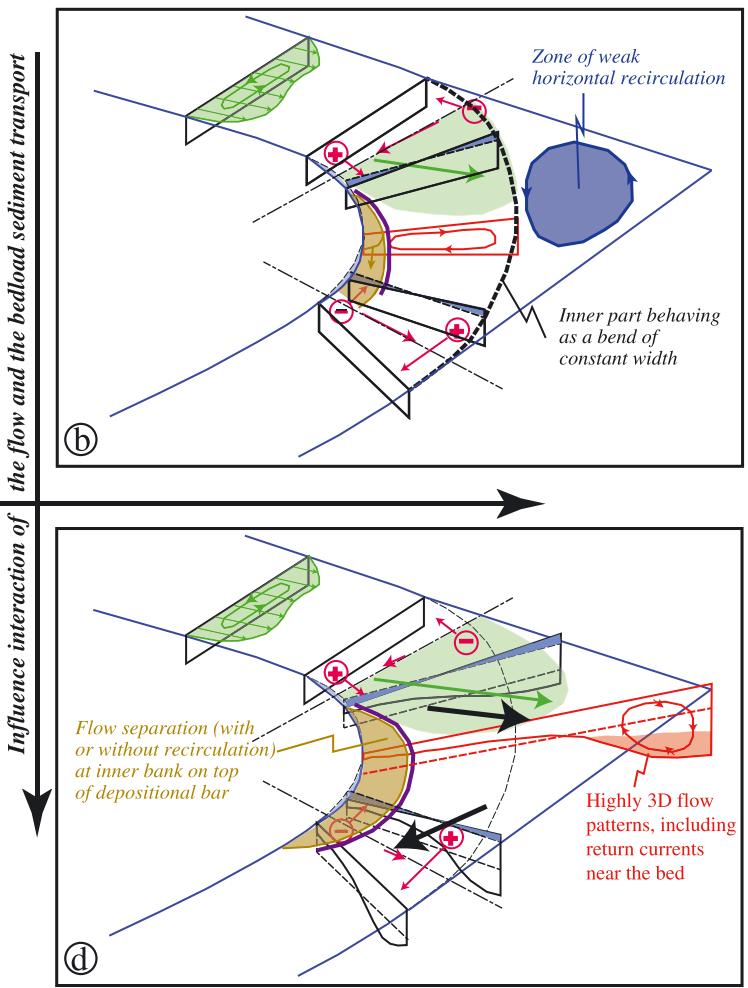

Figure 12. Conceptualization of hydrodynamic processes in sharp open-channel bends. (a) Configuration with constant width and flat immobile bed; (b) configuration with outer-bank widening and flat immobile bed; (c) configuration with constant width and mobile bed; (d) configuration with outer-bank widening and mobile bed. Comparison reveals the influences of the outer-bank widening and the interaction between the flow and the bedload sediment transport on the hydrodynamic processes. 


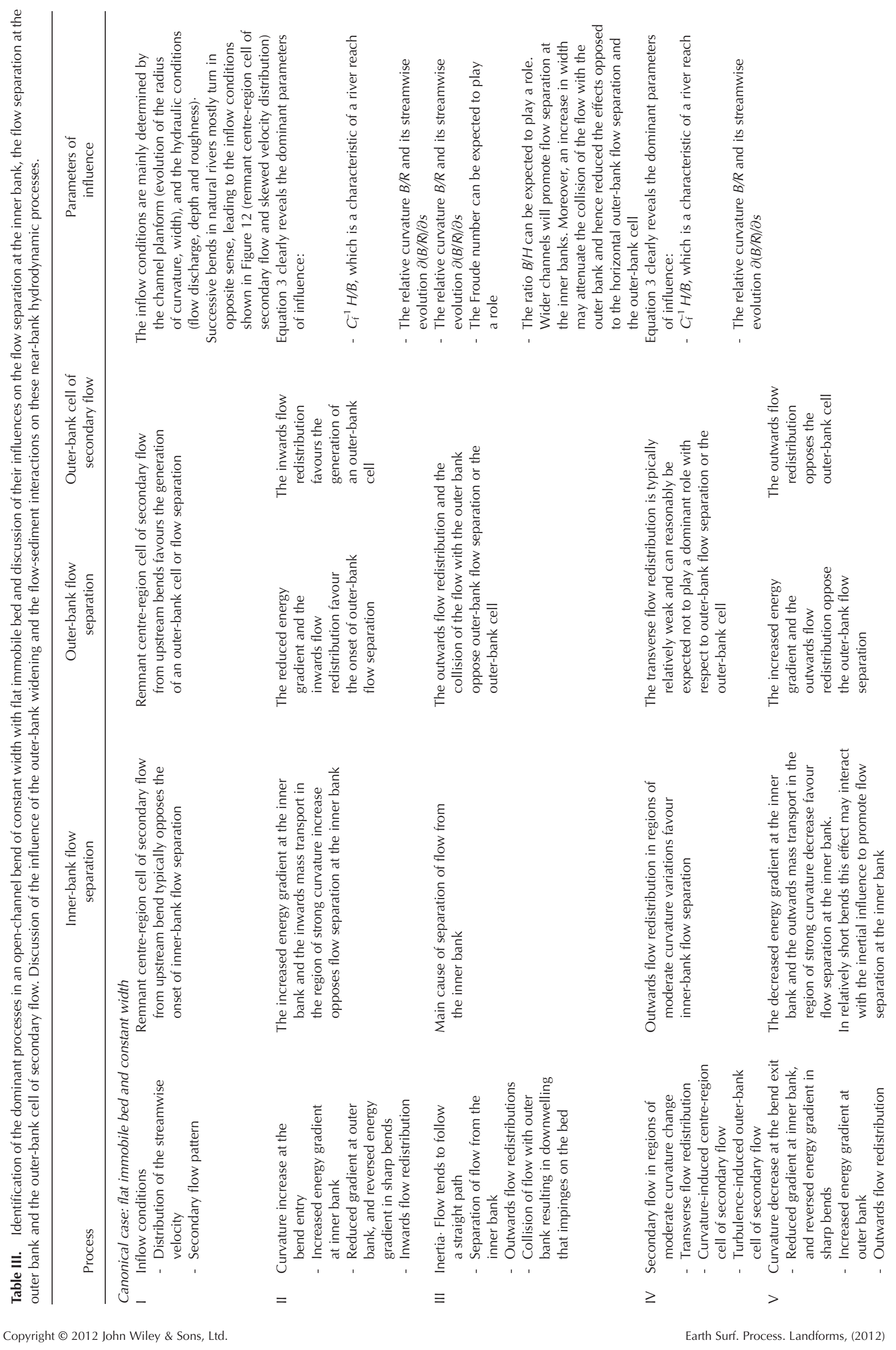



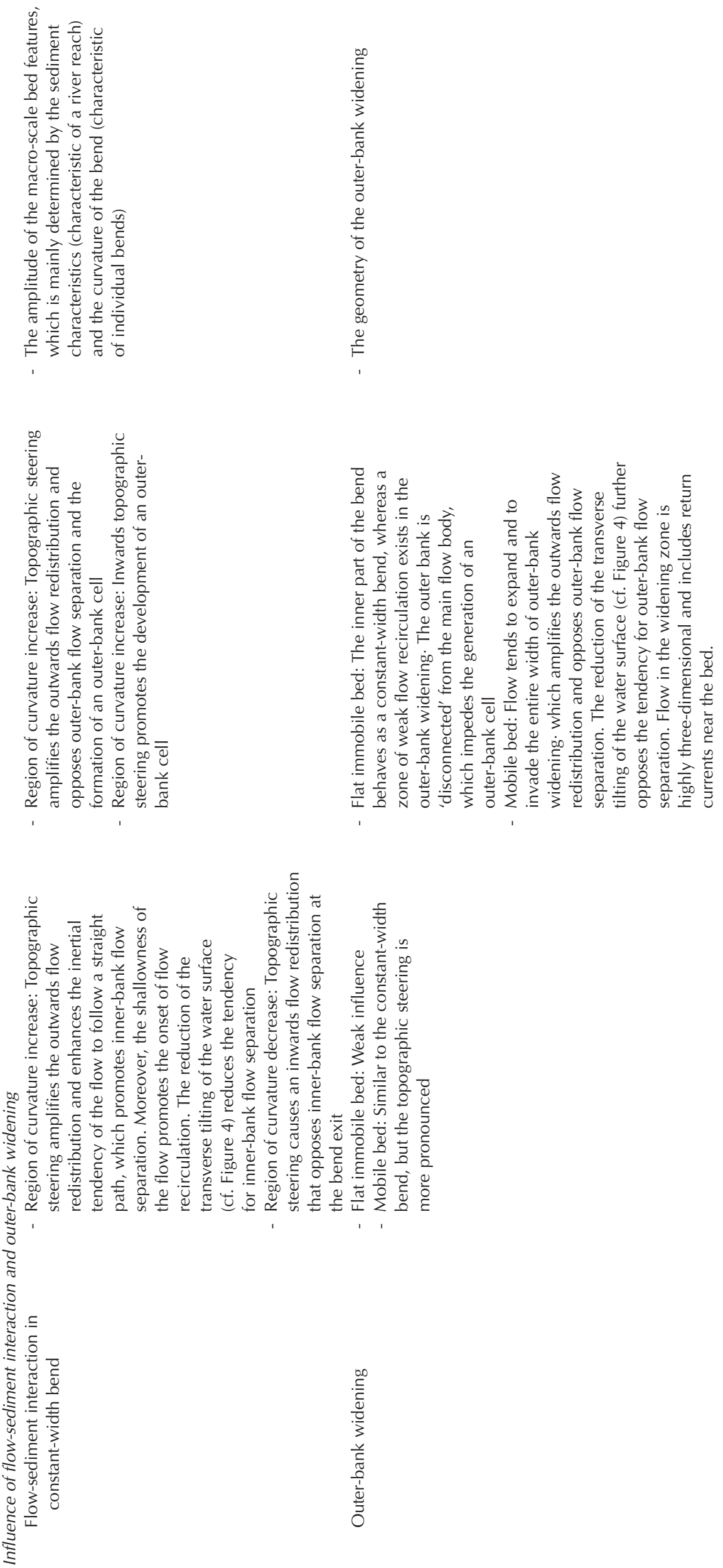
are identified by means of field observations, investigated in detail under controlled laboratory conditions. The validation of numerical models requires such benchmark experimental data that cover a broad range of conditions with respect to the parameters of influence indicated in Table III. The reported experiments fill an essential place in the list of required benchmark cases. After validation, numerical models can: (i) provide the data in the zones were no measurements are available, and thereby reveal the flow field in the regions near the banks, other cross-sections around the bend, or in the outerbank widening, (ii) provide information on variables that are difficult to measure, such as the boundary shear stresses, (iii) allow a broadening of the investigated parameter space, by further varying the parameters of influence indicated in Table III, and thereby bridge the gap between idealized laboratory configurations and the wide variety of open-channel bends occurring in nature. In the context of the results and the discussion below we also suggest some avenues for future combined experimental-numerical research.

First, the results indicate that the interaction between the flow, the bedload sediment transport and the mobile-bed morphology changes considerably the hydrodynamic characteristics. One could loosely state that the complexity of the flow structure is reduced over mobile bed. Indeed, results by van Balen et al. (2010a, 2010b) indicate that to simulate accurately the hydrodynamics a more refined turbulence closure model is required over an immobile-bed compared to a mobile-bed morphology, which suggests that the flow-sediment interaction somewhat simplifies the hydrodynamic characteristics. Insight into the hydrodynamic processes over an immobile-bed is nevertheless essential to isolate boundary-induced complexities in the flow from the effects of dynamic interaction between mobile bed and flow. Notably, the influence of the Froude number should be investigated, which Leeder and Bridges (1975) indicated as an important control parameter with respect to inner-bank flow separation, as well as the influence of the planform geometry as described immediately hereafter.

Second, the results indicate the dominant importance of the variations in curvature. The flow patterns in the first bend over the immobile-bed and mobile-bed configurations are very similar to earlier observations in a sharply-curved $193^{\circ}$ long openchannel bend with smooth vertical banks (Zeng et al., 2008; Blanckaert, 2010, 2011; Blanckaert et al., in press). This indicates that the dominant hydrodynamic processes in such sharply-curved open-channel bends are similar in a relatively broad range of geometric (curvature ratio $R / B$, roughness, bend length) and hydraulic (flow depth and related shallowness, Froude number) conditions. We believe that single bends, consisting of a succession of a straight reach, a constant curvature bend and another straight reach are an appropriate canonical configuration to investigate the near-bank processes of flow separation.

Third, comparison of the here-reported mobile-bed experiment in a relatively short $90^{\circ}$ bend to Blanckaert's (2010, 2011) experiment in a long $193^{\circ}$ bend indicates the importance of the length of the bend, which has never been considered before. In the here-reported mobile-bed experiment, one zone of flow separation occurs at the inner bank of the first bend due to the combined effect of inertia at the bend entry and the adverse pressure gradient at the bend exit (Figure 12a). The bend in Blanckaert's experiment is long enough to avoid interaction between these two mechanisms, resulting in two distinct zones of inner-bank flow separation: one just downstream of the bend entry that is mainly induced by inertia, and the other at the bend exit that is induced by the adverse pressure gradient caused by the vanishing transverse tilting of the water surface (Figure 12a). From this comparison it can be concluded that inner-bank flow separation is promoted in relatively short bends where both mechanisms interact.

Fourth, in line with Page and Nanson (1982), Hodskinson and Ferguson (1998), and Vietz et al. (2012), the results indicate the importance of the flow and morphology conditions at the inflow of the bend, which are essentially determined by the upstream planform geometry. A straightforward extension of the here reported experiments would consist in investigating the effect of the length of the cross-over reach between the first and second bend.

Fifth, the influence of the channel width and the geometry of the outer-bank widening on the hydrodynamic properties should be investigated. Increasing the width in a constantwidth bend reduces the interaction between flow processes at the inner and outer banks (e.g. Hodskinson and Ferguson, 1998). We postulate that an increase in channel width favours transverse flow expansion and the onset of flow separation and recirculation at both banks. Experiments and measurements in nature clearly show that channel widening near the apex of sharply-curved bends promotes outer-bank flow separation (Bagnold, 1960; Leeder and Bridges, 1975; Hickin, 1977; Page and Nanson, 1982; Nanson, 2010). Our immobilebed and mobile-bed experiments indicate that the interaction between flow and bedload sediment transport fundamentally modifies the flow patterns and the characteristics of the flow separation in the outer-bank widening. Thus geometric controls on the onset of separation and recirculation and their characteristics remain unknown. In line with the numerical analysis of Hodskinson and Ferguson (1998), we postulate that the degree of flow expansion and the onset of flow recirculation in the widening region are primarily geometrically controlled.

Sixth, our experiments focused on the interaction of the flow with bedload sediment transport, which is relevant for the formative conditions of the base layer of coarse material in outer-bank benches (see section earlier entitled 'Flow separation and recirculation at the outer bank'). The observations in natural rivers (see earlier) indicate that the interaction of the flow with fine suspended sediment would lead to the deposition of fine sediment at the outer-bank bench, which becomes shallow and planar and where vegetation may develop. This would typically lead to an inward shift of the high velocity thread, and erosion of the inner-bend bar and inner bank. It should be noted that the flow patterns in the immobile-bed experiments represent rather well this type of flow pattern. Additional experimental research is required to clarify the role of graded sediment and sediment transport in suspension.

Seventh, the influence of discharge variability on the investigated morphodynamic processes requires further study. Vietz et al. (2012), for example, investigated whether the flow separation zone, recirculation zone and depositional environment in outer-bank benches are maintained at all flow stages from benchfull to bankfull.

Eighth, field observations indicate that flow separation strongly influences meander evolution. Inner-bank flow separation can lead to an increased erosion of the outer bank and enhanced bend sharpness (Leeder and Bridges, 1975; Andrle, 1994; Ferguson et al., 2003; Kleinhans et al., 2009). Flow separation in outer-bank widenings is often associated with the high-velocity flow impinging on the outer-bank downstream from the apex, and erosion of the inner bank and the associated depositional bar upstream of the bend apex, which can lead to a reduction in bend sharpness (Page and Nanson, 1982; Hodskinson and Ferguson, 1998; Vietz et al., 2012). Most experiments to date have fixed banks, showing a need for erodible-bank experiments in order to investigate the relation of near-bank flow separation to planform evolution. Recent results of erodible-bank experiments with meandering rivers indicate that this is feasible (Van Dijk et al., 2012). 


\section{Conclusions}

Three distinct processes of flow separation near the banks in sharply-curved open-channel bends were investigated: flow separation at the inner bank of a constant-width bend, flow separation at the outer bank in a widening bend, and an outer-bank, horizontal rotational axis cell of secondary flow. In line with previous observations in similar sharp bends, the flow in the constant-width bend with flat immobile bed was characterized by a zone of flow retardation at the inner bank that did not contain flow recirculation, and an outer-bank cell of secondary flow. Surprisingly, the widening at the outer bank in the second bend did not lead to an expansion of the flow in the configuration with immobile bed. The inner part of the bend behaved as a constant-width bend, which hardly interacted with the weak horizontally recirculating flow in the outer-bank widening.

The interaction of the flow and the dominant bedload sediment transport led to the development of a pronounced bed morphology with a depositional bar at the inside of the bend and scour at the outside. The pronounced bed morphology reduced the curvature-induced transverse tilting of the water surface, which is a major driving force for flow separation at the inner and outer banks. Moreover it induced an important topographic steering of the flow, which dramatically modified the hydrodynamic patterns. The topographic steering promoted flow separation, as well as the onset of flow recirculation, including return currents, over the shallow bar near the inner bank. In the constant-width bend, the topographic steering impeded the generation of an outer-bank cell of secondary flow. In the bend with outer-bank widening, the horizontal recirculation in the widening outer bend disappeared as morphology developed. Topographic steering induced an expansion of the flow, whereby the major part of the discharge was conveyed in the central part of the widening section. Flow in the outer-bank widening was highly three-dimensional and included return currents near the bottom.

The following formative conditions of these flow structures were identified. Flow separation is promoted in sharp bends due to flow inertia, which forces the flow to abandon the inner bank and causes deep scour at the projection of flow onto the outer bank. Flow separation is also promoted by a sudden increase of bend radius downstream of the bend apex, where the adjusting transverse water surface slope causes an adverse pressure gradient at the inner bank just downstream of the bend. Flow recirculation is promoted by very shallow flow, in particularly over the shallow bars formed in the inner bends. It did not occur in immobile-bed experiments. The paper discussed the parameters of influence of the investigated flow processes, and discussed how insight can be further enhanced by using the data in complementary combined experimentalnumerical research.

Acknowledgements - Experimental data reported in this paper can be obtained from the authors: ADVP data from Blanckaert, 3D-PIV data from McLelland, LS-PIV data from Kleinhans, bed elevation data from Blanckaert and Kleinhans. The support by Lekan Owodunni for the LS-PIV analysis with the dedicated Flowscout software was appreciated. Support and discussion by Stuart Lane, Richard Hardy, Jeff Peakall, Alex Sukhodolov, Carlo Camporeale, Kees Sloff and Rob Ferguson are gratefully acknowledged. Sean Bennet and an anonymous reviewer are gratefully acknowledged for their input. Access to the TES at Hull University for 30 days was supported by European Community's Sixth Framework Programme through the grant to the budget of the Integrated Infrastructure Initiative HYDRALAB III within the Transnational Access Activities, Contract no. 022441. KB was partially funded by the Chinese Academy of Sciences Visiting Professorship for Senior International Scientists, grant number 2011T2Z24, by the Sino-Swiss Science and
Technology Cooperation for the Institutional Partnership Project, grant number IP13_092911, by the National Natural Science Foundation of China, grant number 50920105907 and by the National Basic Research Program of China 973, grant number 2010CB429004. MGK was supported by the Netherlands Organization for Scientific Research (NWO) (personal research fellowship ALW-Vidi-864.08.007) and DP was supported through a UK NERC Personal Research Fellowship (NE/C002636/1). The authors contributed in the following proportions to conception and design, data collection, data analysis and conclusions, and manuscript preparation: KB $(15,20,50,45) \%$, MGK $(30,20,25$, $30) \%$, SJM $(20,20,10,5) \%$, WSJU $(10,15,5,10) \%$, BJM $(10,15,0$, $0) \%$, AvdK $(0,10,10,0) \%$, DP $(15,0,0,5) \%$ and QC $(0,0,0,5) \%$.

\section{References}

Abad JD, Garcia MH. 2009. Experiments in a high-amplitude Kinoshita meandering channel: 2. Implications of bend orientation on bed morphodynamics. Water Resources Research 45: W02402. DOI: 10.1029/2008WR007017.

Adrian RJ. 2005. Twenty years of particle image velocimetry. Experiments in Fluids 39: 159-169.

Andrle R. 1994. Flow structure and development of circular meander pools. Geomorphology 9: 261-270. DOI: 10.1016/0169-555X(94) 90049-3.

Bagnold RA. 1960. Some Aspects of the Shape of River Meanders, US Geological Survey Professional Papers 282E. US Geological Survey: Reston, VA; 135-144.

Bathurst JC, Thorne CR, Hey RD. 1977. Direct measurements of secondary currents in river bends. Nature 269: 504-506. DOI: 10.1038/269504a0.

Bathurst JC, Thorne CR, Hey RD. 1979. Secondary flow and shear stress at river bends. Journal of the Hydraulics Division American Society of Civil Engineers 105(10): 1277-1295.

Bennet SJ, Best JL. 2006. Mean flow and turbulence structure over fixed, two-dimensional dunes: implications for sediment transport and bedform stability. DOI: 10.1111/j.1365-3091.1995.tb00386.x

Best JL, Brayshaw AC. 1985. Flow separation - a physical process for the concentration of heavy minerals within alluvial channels. Journal of the Geological Society 142: 767-755.

Best JL, Reid I. 1984. Separation zone at open-channel junctions. Journal of Hydraulic Engineering 110(11): 1588-1594.

Blanckaert K. 2009. Saturation of curvature induced secondary flow, energy losses and turbulence in sharp open-channel bends. Laboratory experiments, analysis and modelling. Journal of Geophysical Research - Earth Surface 114: F03015. DOI: 10.1029/2008JF001137.

Blanckaert K. 2010. Topographic steering, flow recirculation, velocity redistribution and bed topography in sharp meander bends. Water Resources Research 46: W09506. DOI: 10.1029/2009WR008303.

Blanckaert K. 2011. Hydrodynamic processes in sharply-curved river bends and their morphological implications. Journal of Geophysical Research - Earth Surface 116: F01003. DOI: 10.1029/2010JF001806.

Blanckaert K, de Vriend HJ. 2003. Non-linear modeling of mean flow redistribution in curved open channels. Water Resources Research 39(12): 1375.

Blanckaert K, de Vriend HJ. 2004. Secondary flow in sharp open-channel bends. Journal of Fluid Mechanics 498: 353-380.

Blanckaert K, de Vriend HJ. 2010. Meander dynamics: a nonlinear model without curvature restrictions for flow in open-channel bends. Journal of Geophysical Research - Earth Surface 115: F04011. DOI: 10.1029/2009JF001301.

Blanckaert K, Duarte A, Chen Q, Schleiss AJ. In press. Flow processes near smooth and rough (concave) outer banks in curved open channels. Journal of Geophysical Research - Earth Surface. DOI: 10.1029/ 2012JF002414.

Blanckaert K, Graf WH. 2001. Mean flow and turbulence in openchannel bend. Journal of Hydraulic Engineering 127(10): 835-847.

Blanckaert K, Graf WH. 2004. Momentum transport in sharp openchannel bends. Journal of Hydraulic Engineering 130(3): 186-198.

Blanckaert K, Lemmin U. 2006. Means of noise reduction in acoustic turbulence measurements. Journal of Hydraulic Research 44(1): $3-17$.

Boussinesq J. 1868. Mémoire sur I'influence de frottement dans les mouvements réguliers des fluides; XII - Essai sur le mouvement 
permanent d'un liquide dans un canal horizontal à axe circulaire. Journal de Mathémathiques Pures et Appliquées 2 XIII: 413.

Bridge JS, Jarvis J. 1977. Velocity profiles and bed shear stress over various bed configurations in a river bend. Earth Surface Processes 2: 281-294. DOI: 10.1002/esp.3290020402.

Bulle H. 1926. Untersuchungen über die Geschiebeableitung bei der Spaltung von Wasserlaüfen. VDI Verlag: Berlin.

Burge LM, Smith DG. 1999. Confined meandering river eddy accretions: sedimentology, channel geometry and depositional processes. In Fluvial Sedimentology VI, Smith ND, Rogers G (eds), Specia Publication of the International Association of Sedimentologists 28. Blackwell Science: Oxford; 113-130.

Chow VT. 1959. Open Channel Hydraulics. McGraw-Hill: New York.

Cohen TJ. 2003. Late Holocene Floodplain Processes and PostEuropean Channel Dynamics in a Partly Confined Valley of NSW, Australia, PhD Thesis, University of Wollongong.

Constantinescu G, Koken M, Zeng J. 2011. The structure of turbulent flow in an open channel bend of strong curvature with deformed bed: insight provided by detached eddy simulation. Water Resources Research 47: W05515. DOI: 10.1029/2010WR010114.

Crosato A. 2008. Analysis and Modelling of River Meandering, PhD Thesis, Delft University of Technology.

de Vriend HJ. 1977. A mathematical model of steady flow in curved shallow channels. Journal of Hydraulic Research 15(1): 37-54.

de Vriend HJ. 1981. Steady Flow in Shallow Channel Bends, Report No. 81-3. Laboratory of Fluid Mechanics, Department of Civil Engineering, Delft University of Technology: Delft.

de Vriend HJ, Geldof HJ. 1983. Main Flow Velocity in Short and Sharply Curved River Bends, Report 83-6. Laboratory of Fluid Mechanics, Department of Civil Engineering, Delft University of Technology: Delft.

Dietrich WE. 1987. Mechanics of flow and sediment transport in river bends. In River Channels: Environment and Process, Richards K (ed.), Institute of British Geographers Special Publication 18. Blackwell: Oxford; 179-227.

Dietrich WE, Smith JD. 1983. Influence of the point bar on flow through curved channels. Water Resources Research 19(5): 1173-1192.

Duarte A. 2008. An Experimental Study on Main Flow, Secondary Flow and Turbulence in Open-channel Bends with Emphasis on their Interaction with the Outer-bank Geometry, PhD Thesis 4227, Ecole Polytechnique Fédérale, Lausanne.

Einstei HA, Harder JA. 1954. Velocity distribution and the boundary layer at channel bends. Transactions AGU 35(1): 114-120.

Engelund F. 1974. Flow and bed topography in channel bends. Journal of the Hydraulics Division American Society of Civil Engineers 100(HY11): 1631-1648.

Erskine WD, Livingstone EL. 1999. In-channel benches: the role of floods in their formation and destruction on bedrock-confined rivers. In Varieties of Fluvial Form. Miller AJ, Gupta A (eds). John Wiley \& Sons: Chichester; 445-475.

Ferguson R. 1987. Hydraulic and sedimentary controls of channel pattern. In River Channels: Environment and Process, Richards K (ed.), Institute of British Geographers Special Publication 18. Blackwell: Oxford; 129-158.

Ferguson RI, Parsons DR, Lane SN, Hardy RJ. 2003. Flow in meander bends with recirculation at the inner bank. Water Resources Research 39(11): 1322. DOI: 10.1029/2003WR001965.

Frothingham KM, Rhoads BL. 2003. Three-dimensional flow structure and channel change in an asymmetrical compound meander loop, Embarras River, Illinois. Earth Surface Processes and Landforms 28(6): 625-644.

Hardy RJ, Best JL, Lane SN, Carbonneau P. 2009. Coherent flow structures in a depth-limited flow over a gravel surface: the role of nearbed turbulence and influence of Reynolds number. Journal of Geophysical Research 114: F01003.

Hey RD, Thorne CR. 1975. Secondary flow in river channels. Area 7(3): 191-195.

Hickin EJ. 1974. The development of meanders in natural river channels. American Journal of Science 274: 414-442. DOI: 10.2475/ajs.274.4.414.

Hickin EJ. 1977. Hydraulic factors controlling channel migration. In Research into Fluvial Systems, Davidson-Arnott RE, Nickling W (eds), Proceedings of the 5th Guelph Geomorphology Symposium. Geobooks: Norwich; 59-72.
Hickin EJ. 1978. Mean flow structure in meanders of the Squamish River, British Columbia. Canadian Journal of Earth Sciences 15(11): 1833-1849.

Hickin EJ. 1986. Concave-bank benches in the floodplains of Muskwa and Fort Nelson Rivers, British Columbia. The Canadian Geographer 30(2): 111-122.

Hickin EJ, Nanson GC. 1975. The character of channel migration on the Beatton River, northeast British Columbia, Canada. Geological Society of America Bulletin 86: 487-494. DOI: 10.1130/0016-7606 (1975) 86 < 487: TCOCMO > 2.0.CO;2

Hickin EJ, Nanson GC. 1984. Lateral migration rates of river bends. Journal of Hydraulic Engineering 110(11): 1557-1567: DOI. 10.1061/(ASCE) 0733-9429(1984)110:11(1557).

Hirose K, Hasegawa K, Meguro H. 2003. Experiments and analysis on mainstream alternation in a bifurcated channel in mountain rivers. In River, Coastal and Estuarine Morphodynamics, Sanchez-Arcilla A, Bateman A (eds). IAHR: Madrid; 571-583.

Hodskinson A, Ferguson RI. 1998. Numerical modelling of separated flow in river bends: model testing and experimental investigation of geometric controls on the extent of flow separation at the concave bank. Hydrological Processes 12: 1323-1338.

Hurther D, Lemmin U. 1998. A constant beam width transducer for three-dimensional Doppler profile measurements in open channel flow. Measurement Science and Technology 9(10): 1706-1714.

Ikeda S, Parker G, Sawai K. 1981. Bend theory of river meanders. Part 1. Linear development. Journal of Fluid Mechanics 112: 363-377. DOI: $10.1017 /$ S0022112081000451.

Jackson AD. 1992. Bedload Transport and Sorting in Meander Bends, Fall River, Rocky Mountain National Park, Colorado, PhD Thesis, Colorado State University, Fort Collins, CO.

Jamieson EC, Post G, Rennie CD. 2010. Spatial variability of threedimensional Reynolds stresses in a developing channel bend. Earth Surface Processes and Landforms 35: 1029-1043.

Johannesson H, Parker G. 1989. Secondary flow in a mildly sinuous channel. Journal of Hydraulic Engineering 115(3): 289-308.

Kang S, Sotiropoulos F. 2011. Flow phenomena and mechanisms in a fieldscale experimental meandering stream with a pool-riffle sequence: insight gained via numerical simulation. Journal of Geophysical Research - Earth Surface 116: F03011. DOI: 10.1029/2010JF001814.

Khosronejad A, Rennie C, Neyshabouri S, Townsend RD. 2007. 3D numerical modeling of flow and sediment transport in laboratory channel bends. Journal of Hydraulic Engineering 133(10): 1123-1134.

Kikkawa H, Ikeda S, Kitagawa A. 1976. Flow and bed topography in curved open channels. Journal of the Hydraulics Division 102(HY9): 1327-1342.

Kleinhans MG. 2010. Sorting out river channel patterns. Progress in Physical Geography 34: 287-326.

Kleinhans MG, de Haas T, Lavooi E, Makaske B. 2012. Evaluating competing hypotheses for the origin and dynamics of river anastomosis. Earth Surface Processes and Landforms 37(12): 1337-1351. Published 09.30.2012. DOI: 10.1002/esp.3282.

Kleinhans MG, Schuurman F, Bakx W, Markies H. 2009. Meandering channel dynamics in highly cohesive sediment on an intertidal mud flat in the Westerschelde estuary, the Netherlands. Geomorphology 105: 261-276.

Leeder MR, Bridges PH. 1975. Flow separation in meander bends. Nature 253(5490): 338-339.

Leschziner MA, Rodi W. 1979. Calculation of strongly curved openchannel flow. Journal of the Hydraulics Division American Society of Civil Engineering 105(10): 1297-1314.

Lemmin U, Rolland T. 1997. Acoustic velocity profiler for laboratory and field studies. Journal of Hydraulic Engineering 123(12): 1089-1098.

Makaske B, Weerts HJT. 2005. Muddy lateral accretion and low stream power in a sub-recent confined channel belt, Rhine-Meuse delta, central Netherlands. Sedimentology 52: 651-668.

Markham AJ, Thorne CR. 1992. Geomorphology of gravel-bed river bends. In Dynamics of Gravel-bed Rivers, Billi P., et al. (eds). John Wiley \& Sons: Chichester; 433-456.

Mockmore CA. 1943. Flow around bends in stable channels. Transactions of the American Society of Civil Engineers 109: 593-628.

Nanson RA. 2010. Flow fields in tightly curving meander bends of low width-depth ratio. Earth Surface Processes and Landforms 35(2): 119-135. 
Nanson GC, Page KJ. 1983. Lateral accretion of fine grained concave benches on meandering rivers. In Modern and Ancient Fluvial Systems, Collinson J, Lewin J (eds), International Association of Sedimentology Special Publications 6. International Association of Sedimentology: Gent; 133-145.

Nezu I, Nakagawa H. 1993. Turbulence in Open-channel Flows. Balkema: Rotterdam.

Odgaard AJ. 1981. Transverse bed slope in alluvial channel bends. Journal of the Hydraulics Division American Society of Civil Engineers 107(HY12): 1677-1693.

Odgaard AJ, Bergs MA. 1988. Flow processes in a curved alluvial channel. Water Resources Research 24: 45. DOI: 10.1029/NR024i001 p00045.

Ottevanger W, Blanckaert K, Uijttewaal WSJ. 2012. Processes governing the flow redistribution in sharp river bends. Geomorphology 163-164: 45-55.

Page KJ, Nanson GC. 1982. Concave-bank benches and associated floodplain formation. Earth Surface Processes and Landforms 7: 529-543.

Parsons DR. 2003. Flow separation in meander bends, PhD thesis, University of Sheffield, U. K. 294 pp.

Parsons DR, Best JL, Lane SN, Orfeo O, Hardy RJ, Kostaschuk R. 2007. Form roughness and the absence of secondary flow in a large confluence-diffluence, Rio Parana, Argentina. Earth Surface Processes and Landlforms 32: 155-162. DOI: 10.1002/esp.1457.

Rhoads BL, Massey KD. 2012. Flow structure and channel change in a sinuous grass-lined stream within an agricultural drainage ditch: implications for ditch stability and aquatic habitat. River Research and Applications 28(1): 39-52. DOI: 10.1002/rra.1430.

Rozovskii IL. 1957. Flow of Water in Bends of Open Channels. Academy of Sciences of the Ukrainian SSR: Kiev (translated from Russian by the Israel Program for Scientific Translations, Jerusalem, 1961).

Schmidt JC. 1990. Recirculating flow and sedimentation in the Colorado River in Grand Canyon, Arizona. Journal of Geology 98: 709-724.

Schmidt JC, Rubin DM, Ikeda H. 1993. Flume simulation of recirculating flow and sedimentation. Water Resources Research 29(8): 2925-2939.

Schnauder I, Sukhodolov AN. 2012. Flow in a tightly curving meander bend: effects of seasonal changes in aquatic macrophyte cover. Earth Surface Processes and Landforms 37(11): 1142-1157. Published 09.15.2012. DOI: 10.1002/esp.3234.

Shimizu Y, Itakura T. 1989. Calculation of bed variation in alluvial channels. Journal of the Hydraulics Division American Society of Civil Engineers 115(3): 367-384. DOI: 10.1061/(ASCE)0733-9429 (1989)115:3(367).

Stoesser T, Rüther N, Olsen NRB. 2010. Calculation of primary and secondary flow and boundary shear stresses in a meandering channel. Advances in Water Resources 33(2): 158-170.

Struiksma N, Olesen KW, Flokstra C, de Vriend HJ. 1985. Bed deformation in curved alluvial channels. Journal of Hydraulic Research 23(1): 57-79.

Talmon AM, van Mierlo MCLM, Struiksma N. 1995. Laboratory measurements of the direction of sediment transport on transverse alluvial-bed slopes. Journal of Hydraulic Research 33(4): 495-517.
Termini D, Piraino M. 2011. Experimental analysis of cross-sectional flow motion in a large amplitude meandering bend. Earth Surface Processes and Landforms 36: 244-256.

Thomson W. 1876. On the origin of windings of rivers in alluvial plains, with remarks on the flow of water round bends in pipes. Proceedings of the Royal Society of London 25: 5-8.

Thorne CR, Hey RD. 1979. Direct measurements of secondary currents at a river inflexion point. Nature 280: 226-228. DOI: 10.1038/280226a0

Thorne CR, Zevenbergen LW, Pitlick JC, Rais S, Bradley JB, Julien PY. 1985. Direct measurement of secondary currents in a meandering sand-bed river. Nature 315: 746-747. DOI: 10.1038/315746a0.

Uijttewaal WSJ, Lehmann D, van Mazijk A. 2001. Exchange processes between a river and its groyne fields; model experiments. Journal of Hydraulic Engineering 127(11): 928-936.

Van Balen W, Uijttewaal WSJ, Blanckaert K. 2009. Large-eddy simulation of a mildly curved open-channel flow. Journal of Fluid Mechanics $\mathbf{6 3 0}$ : 413-442.

Van Balen W, Blanckaert K, Uijttewaal WSJ. 2010a. Analysis of the role of turbulence in curved open-channel flow at different water depths by means of experiments, LES and RANS. Journal of Turbulence 11(12): 1-34. Published 04.23.2010. DOI: 10.1080/14685241003789404.

Van Balen W, Uijttewaal WSJ, Blanckaert K. 2010b. Large-eddy simulation of a curved open-channel flow over topography. Physics of Fluids 22: 075108. DOI: 10.1063/1.3459152.

Van Bendegom L. 1947. Eenige beschouwingen over riviermorphologie en rivierverbetering. De Ingenieur 59(4): 1-11 (in Dutch).

Van Dijk WM, van de Lageweg WI, Kleinhans MG. 2012. Experimental meandering river with chute cutoffs. Journal of Geophysical Research 117: F03023. DOI: 10.1029/2011JF002314.

Vietz GJ, Stewardson MJ, Rutherfurd ID, Finlayson BL. 2012. Hydrodynamics and sedimentation of concave benches in a lowland river. Geomorphology 147-148: 86-101. DOI: 10.1016/j.geomorph.2011.07.033.

Whiting PJ, Dietrich WE. 1993. Experimental studies of bed topography and flow patterns in large-amplitude meanders: 1 . Observations. Water Resources Research 29: 3605-3614. DOI: 10.1029/93WR01755.

Woodyer KD, Taylor G, Crook KAW. 1979. Depositional processes along a very low gradient, suspended-load stream: the Barwon River, New South Wales. Sedimentary Geology 22: 97-120.

Wright SA, Kaplinski M. 2011. Flow structures and sandbar dynamics in a canyon river during a controlled flood, Colorado River, Arizona. Journal of Geophysical Research - Earth Surface 116: F01019.

Wu W, Rodi W, Wenka T. 2000. 3D numerical modeling of flow and sediment transport in open channels. Journal of Hydraulic Engineering 126(1): 4-15.

Yeh KC, Kennedy JF. 1993. Moment model of nonuniform channelbend flow. I. Fixed beds. Journal of Hydraulic Engineering 119(7): 776-795.

Zeng J, Constantinescu G, Blanckaert K, Weber L. 2008. Flow and bathymetry in sharp open channel bends: experiments and predictions. Water Resources Research 44: W09401.

Zimmerman C, Kennedy JF. 1978. Transverse bed slopes in curved alluvial channels. Journal of Hydraulic Engineering 104: 33-48. 